Published in "Organometallics 27(13): 3161-3171, 2008"

which should be cited to refer to this work.

\title{
Rhodium(III) Complexes Containing C4-Bound N-Heterocyclic Carbenes: Synthesis, Coordination Chemistry, and Catalytic Activity in Transfer Hydrogenation
}

\author{
Liangru Yang, ${ }^{\dagger}{ }^{\S}$ Anneke Krüger ${ }^{\dagger}$ Antonia Neels, ${ }^{\ddagger}$ and Martin Albrecht* ${ }^{\dagger}$ \\ Department of Chemistry, University of Fribourg, Chemin du Musée 9, 1700 Fribourg, \\ Switzerland, and Institute of Microtechnology, University of Neuchâtel, Rue Jaquet-Droz, 1, \\ 2002 Neuchâtel, Switzerland
}

Direct metalation of C2-protected diimidozolium salts with $\mathrm{RhCl}_{3}$ or $[\mathrm{RhCl}(\mathrm{cod})]_{2}$ and $\mathrm{KI}$ afforded a series of new rhodium(III) complexes with abnormally C4-bound, cis-chelating NHC ligands. The complexes were isolated as dimetallic species containing two $\left(\mu^{2}-\mathrm{I}\right)_{3}$-bridged rhodium(III) centers. In the presence of coordinating ligands such as $\mathrm{CH}_{3} \mathrm{CN}, \mathrm{PPh}_{3}$, or dppe, the dimeric structure is readily cleaved and yields monometallic complexes. Crystallographic analysis of representative structures indicates a higher trans influence of abnormally C4-bound carbenes as compared to normal NHCs. The exceptionally strong donor ability of carbenes in such a $\mathrm{C} 4$ coordination mode increases the catalytic activity of the rhodium center and allows for efficient transfer hydrogenation of ketones in $i \mathrm{PrOH} / \mathrm{KOH}$.

\section{Introduction}

$\mathrm{N}$-Heterocyclic carbenes (NHCs) have emerged as a very powerful class of ligands in organometallic chemistry and homogeneous catalysis. ${ }^{1}$ Most of the reported NHCs are derived from imidazolium salts and bind the metal via the $\mathrm{C} 2$ carbon (Chart 1) and hence comprise a classical carbene bonding mode. ${ }^{2}$ Recently, it has been reported that, under specific conditions, metalation of imidazolium salts takes place at the $\mathrm{C} 4$ or $\mathrm{C} 5$

* To whom correspondence should be addressed. E-mail: martin.albrecht@ unifr.ch. Fax: +41-263009738.

University of Fribourg.

$\doteqdot$ University of Neuchâtel.

$\S$ Current address: School of Chemistry and Chemical Engineering, Henan University of Techology, P. R. China.

(1) (a) Arduengo, A. J. Acc. Chem. Res. 1999, 32, 913. (b) Bourissou, D.; Guerret, O.; Gabbai, F. P.; Bertrand, G. Chem. Rev. 2000, 100, 39. (c) Herrmann, W. A. Angew. Chem., Int. Ed. 2002, 41, 1290. (d) Hahn, F. E. Angew. Chem., Int. Ed. 2008, 47, 3122. (e) Topics in Organometallic Chemistry; Glorius F., Ed; 2007; Vol. 21. (f) Coord. Chem. Rev. (Crabtree, R. H. Ed.) 2005, 251, 5-6. (g) J. Organomet. Chem. (Bertrand, G., Ed.) 2005, 690, 23-25. (h) N-heterocyclic carbenes in synthesis; Nolan, S. P., Ed.; Wiley-VCH: Weinheim, 2006.

(2) For representative examples of NHC ligands that are not derived from imidazolium salts, see:(a) Fraser, P. J.; Roper, W. R.; Stone, F. G. A. J. Chem. Soc., Dalton Trans. 1974, 760. (b) Crociani, B.; Di Bianca, F.; Giovenco, A.; Berton, A. J. Organomet. Chem. 1987, 323, 123. (c) Cave, G. W. V.; Hallett, A. J.; Errington, W.; Rourke, J. P. Angew. Chem., Int. Ed. 1998, 37, 3270. (d) Koizumi, T.; Tomon, T.; Tanaka, K. Organometallics 2003, 22, 970. (e) Owen, J. S.; Labinger, J. A.; Bercaw, J. E. J. Am. Chem. Soc. 2004, 126, 8247. (f) Lavallo, V.; Canac, Y.; Präsang, C.; Donnadieu, B.; Bertrand, G. Angew. Chem., Int. Ed. 2005, 44, 5705. (g) Lavallo, V.; Canac, Y.; DeHope, A.; Donnadieu, B.; Bertrand, G. Angew. Chem., Int. Ed. 2005, 44, 7236. (h) Schneider, S. K.; Roembke, P.; Julius, G. R.; Loschen, C.; Raubenheimer, H. G.; Frenking, G.; Herrmann, W. A. Eur. J. Inorg. Chem. 2005, 2973. (i) Herrmann, W. A.; Schuetz, J.; Frey, G. D.; Herdtweck, E. Organometallics 2006, 25, 2437. (j) Alvarez, E.; Conejero, S.; Paneque, M.; Petronilho, A.; Poveda, M. L.; Serrano, O.; Carmona, E. J. Am. Chem. Soc. 2006, 128, 13060. (k) Esteruelas, M. A.; Fernandez-Alvarez, F. J.; Onate, E. J. Am. Chem. Soc. 2006, 128, 13044. (1) Han, Y.; Huynh, H. V.; Tan, G. K. Organometallics 2007, 26, 6581. (m) Kessler, F.; Szesni, N.; Maass, C.; Hohberger, C.; Weibert, B.; Fischer, H. J. Organomet. Chem. 2007, 692, 3005. (n) Raubenheimer, H. G.; Cronje, S. Dalton Trans. 2008, 1265.
Chart 1. Normally C2-Bound Imidazolylidene Ligand (A) and Abnormally C4-Bound Carbene Ligand (B)

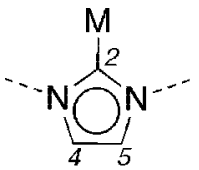

A

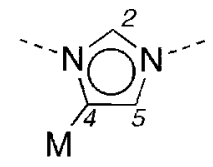

B position (Chart 1). ${ }^{3}$ These so-called abnormal carbenes are exceptionally basic ligands with a higher donor power than their C2-bound analogues. ${ }^{4,5}$ The first evidence has been provided for the beneficial impact of such C4-bound carbenes on the catalytic activity of the coordinated metal center. ${ }^{5,6}$

Theoretical investigations on the reactivity of imidazolium salts have indicated that formation of the free $\mathrm{C} 4$-carbene is less favored than the C2-carbene by approximately $80 \mathrm{~kJ} \mathrm{~mol}^{-1}$. Similarly, the $\mathrm{p} K_{\mathrm{a}}$ of the C4-bound hydrogen has been calculated to be about $5-8 \mathrm{p} K_{\mathrm{a}}$ units higher ${ }^{8}$ than that of the hydrogen attached to C2. ${ }^{9}$ Despite these drawbacks, various methods have been established for installing the metal selectively at the $\mathrm{C} 4$

(3) (a) Gründemann, S.; Kovacevic, A.; Albrecht, M.; Faller, J. W.; Crabtree, R. H. Chem. Commun. 2001, 2274. (b) Gründemann, S.; Kovacevic, A.; Albrecht, M.; Faller, J. W.; Crabtree, R. H. J. Am. Chem. Soc. 2002, 124, 10473.

(4) Chianese, A. R.; Kovacevic, A.; Zeglis, B. M.; Faller, J. W.; Crabtree, R. H. Organometallics 2004, 23, 2461.

(5) Heckenroth, M.; Kluser, E.; Neels, A.; Albrecht, M. Angew. Chem., Int. Ed. 2007, 46, 6293.

(6) (a) Lebel, H.; Janes, M. K.; Charette, A. B.; Nolan, S. P. J. Am. Chem. Soc. 2004, 126, 5046. (b) Campeau, L.; Thansandote, P.; Fagnou, K. Org. Lett. 2005, 7, 1857.

(7) (a) Sini, G.; Eisenstein, O.; Crabtree, R. H. Inorg. Chem. 2002, 41, 602. (b) Tonner, R.; Heydenrych, G.; Frenking, G. Chem. Asian J. 2007, 2,1555 .

(8) (a) Magill, A. M.; Yates, B. F. Aust. J. Chem. 2004, 51, 1205. (b) Ehlers, A. Personal communication. 

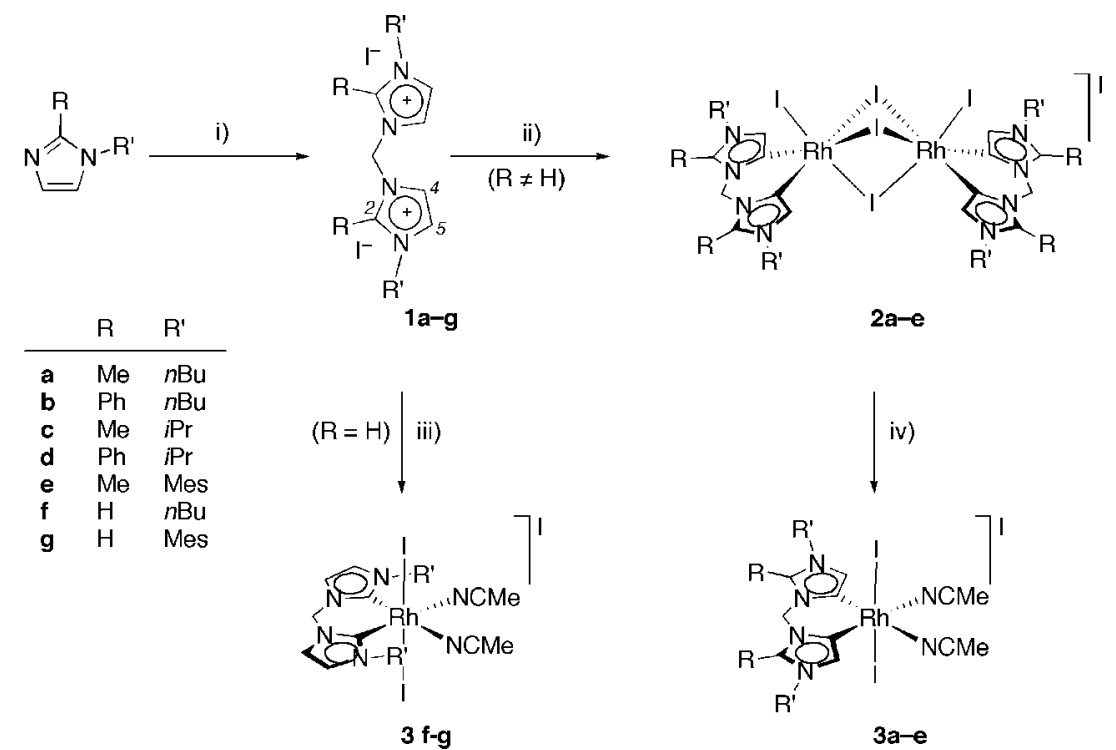

${ }^{a}$ Reagents and conditions: (i) $\mathrm{CH}_{2} \mathrm{I}_{2}$, toluene, reflux; (ii) [ $\left.\mathrm{RhCl}(\mathrm{cod})\right]_{2}, \mathrm{NaOAc}, \mathrm{KI}, \mathrm{MeCN}$, reflux, or $\mathrm{RhCl}{ }_{3}, \mathrm{NaOAc}, \mathrm{MeCN}$, reflux, then $\mathrm{NaI}$, acetone; (iii) $[\mathrm{RhCl}(\mathrm{cod})]_{2}, \mathrm{NaOAc}, \mathrm{KI}, \mathrm{MeCN}, 60{ }^{\circ} \mathrm{C}$; (iv) $\mathrm{MeCN}, \mathrm{RT}$.

position. ${ }^{10}$ Some approaches are highly reagent-specific such as oxidative $\mathrm{C}-\mathrm{H}$ bond activation, ${ }^{11}$ rearrangement of $\mathrm{C} 2$ imidazolylidenes, ${ }^{12}$ and anion-triggered differentiation between the $\mathrm{C} 2-\mathrm{H}$ and $\mathrm{C} 4-\mathrm{H}$ positions. ${ }^{3,13}$ A more general access to C4-bound NHC complexes consists of quaternizing an anionic azolyl ligand ${ }^{14}$ or using halide-functionalized imidazolium salts for oxidative addition. ${ }^{15}$ A particularly useful route was introduced by Crabtree and co-workers and relies on the protection of the imidazolium $\mathrm{C} 2$ position, ${ }^{4}$ typically by an alkyl or aryl substituent. ${ }^{16}$ On the basis of this approach, we have recently prepared chelating $\mathrm{C} 4$-bound dicarbene palladium complexes. ${ }^{5}$ Owing to the rigid cis-chelation of the dicarbene and the strong donor power of the ligand, these complexes are significantly better catalysts for olefin hydrogenation than their C2-bound analogues. These results stimulated our interest in extending the abnormal carbene concept to different catalytic processes where bond activation requires electron-rich metal

(9) (a) Amyes, T. L.; Diver, S. T.; Richard, J. P.; Rivas, F. M.; Toth, K. J. Am. Chem. Soc. 2004, 126, 4366. (b) Magill, A. M.; Cavell, K. J.; Yates, B. F. J. Am. Chem. Soc. 2004, 126, 8717. (c) Kim, Y.-J.; Streitwieser, A. J. Am. Chem. Soc. 2002, 124, 5757. (d) Alder, R. W.; Allen, P. R.; Williams, S. J. J. Chem. Soc., Chem. Commun. 1995, 1267.

(10) Arnold, P. L.; Pearson, S. Coord. Chem. Rev. 2007, 251, 596.

(11) Bacciu, D.; Cavell, K. J.; Fallis, I. A.; Ooi, L. Angew. Chem., Int. Ed. 2005, 44, 5282 .

(12) (a) Hu, X.; Castro-Rodriguez, I.; Meyer, K. Organometallics 2003, 22, 3016. (b) Danopoulos, A. A.; Tsoureas, N.; Wright, J. A.; Light, M. E. Organometallics 2004, 23, 166. (c) Stylianides, N.; Danopoulos, A. A.; Tsoureas, N. J. Organomet. Chem. 2005, 690, 5948. (d) Ellul, C. E.; Mahon, M. F.; Saker, O.; Whittlesey, M. K. Angew. Chem., Int. Ed. 2007, 46, 6343. (13) Baya, M.; Eguillor, B.; Esteruelas, M. A.; Olivan, M.; Onate, E. Organometallics 2007, 26, 6556.

(14) (a) Raubenheimer, H. G.; Desmet, M.; Olivier, P.; Kruger, G. J. J. Chem. Soc., Dalton Trans. 1996, 4431. (b) Desmet, M.; Raubenheimer, H. G.; Kruger, G. J. Organometallics 1997, 16, 3324.

(15) Kluser, E.; Neels, A.; Albrecht, M. Chem. Commun. 2006, 4495.

(16) (a) Chianese, A. R.; Zeglis, B. M.; Crabtree, R. H. Chem. Commun. 2004, 2176. (b) Viciano, M.; Feliz, M.; Corberan, R.; Mata, J. A.; Clot, E.; Peris, E. Organometallics 2007, 26, 5304. (c) Alcarazo, M.; Roseblade, S. J.; Cowley, A. R.; Fernandez, R.; Brown, J. M.; Lassaletta, J. M. J. Am. Chem. Soc. 2005, 127, 3290. (d) Arnold, P. L.; Liddle, S. T. Organometallics 2006, $25,1485$. centers. ${ }^{17}$ Here we report on the synthesis and (catalytic) reactivity of the first rhodium(III) complexes bound to $\mathrm{C} 4$ coordinating N-heterocyclic dicarbenes. Most strikingly, the catalytic activity of the rhodium center in transfer hydrogenation is markedly increased when bound to $\mathrm{C} 4$ - rather than $\mathrm{C} 2$ coordinating carbenes. These results underline the high potential of this class of carbene ligands in catalysis.

\section{Results and Discussion}

Synthesis of the Ligands and Rhodium(III) Complexes. The C2-protected diimidazolium salts $\mathbf{1 a}-\mathbf{e}$ were prepared from the corresponding 1,2-disubstituted imidazoles ${ }^{18}$ by condensation with $\mathrm{CH}_{2} \mathrm{I}_{2}$ in an apolar solvent (Scheme 1). ${ }^{19}$ Complexation of these ligand precursors was accomplished according to a procedure similar to the one established for the metalation of C2-bonding dicarbene precursors. ${ }^{20}$ Reaction of the C2-protected diimidazolium salts $\mathbf{1 a}-\mathbf{e}$ with $[\mathrm{RhCl}(\operatorname{cod})]_{2}(\operatorname{cod}=1,5-$ cyclooctadiene) in the presence of iodide ions and acetate as a mild base induced $\mathrm{C}-\mathrm{H}$ bond activation and metalation at the $\mathrm{C} 4$ position (Scheme 1). ${ }^{21}$ Purification by column chromatography and subsequent recrystallization afforded the rhodium(III) complexes $\mathbf{2} \mathbf{a}-\mathbf{e}$ as dimeric tris- $\left(\mu^{2}\right.$-iodo)-bridged species. Notably, no methyl $\mathrm{C}-\mathrm{H}$ bond activation was detected when using ligand 1a, 1c, or 1e. This contrasts with previous metalation results using $\operatorname{Ag}(\mathrm{I})$ and $\operatorname{Ir}(\mathrm{III})$ precursors, where

(17) (a) Cornils B.; Herrmann, W. A. Applied Homogeneous Catalysis with Organometallic Compounds; VCH: New York, 2002. (b) Labinger, J. A.; Bercaw, J. E. Nature 2002, 417, 507. (c) Activation and Functionalization of $\mathrm{C}-\mathrm{H}$ Bonds; Goldberg, K. I., Goldman, A. S., Eds.; ACS Symposium. Series 885; American Chemical Society: Washington DC, 2004.

(18) Gridnev, A. A.; Mihaltseva, I. M. Synth. Commun. 1994, 24, 1547.

(19) Williams, D. J.; Vanderveer, D.; Jones, R. L.; Menaldino, D. S. Inorg. Chim. Acta 1989, 165, 173.

(20) (a) Albrecht, M.; Crabtree, R. H.; Mata, J.; Peris, E. Chem. Commun. 2002, 32. (b) Albrecht, M.; Miecznikowski, J. R.; Samuel, A.; Faller, J. W.; Crabtree, R. H. Organometallics 2002, 21, 3596.

(21) Formally, metalation of the diimidazolium precursors $\mathbf{1}$ occurs at the $\mathrm{C} 5$ position. For reasons of consistency with the literature, the atom numbering as shown in Chart 1 is adopted here. 
$\mathrm{C}_{\text {alkyl }}-\mathrm{H}$ activation and carbene formation are competitive processes. ${ }^{16 \mathrm{a}, \mathrm{b}}$

While some of the metalation yields were rather low, they were consistently higher when the complexation was performed in air rather than under rigorous argon atmosphere. This suggests a cascade-type mechanism, in which iodide is oxidized to iodine, perhaps mediated by oxygen, followed by $\mathrm{I}_{2}$ oxidation of the metal center to the rhodium(III) species. Indeed, performing the metalation with commercially available $\mathrm{RhCl}_{3}$ as rhodium(III) precursor induced straightforward complexation and afforded the dicarbene complex 4, which was converted into complex 2b by halide metathesis (eq 1). Starting directly from rhodium(III) precursors provides a simplified metalation procedure, and in addition, the product is formed in higher purity and yield as compared to metalation with $[\mathrm{RhCl}(\mathrm{cod})]_{2}$. These results suggest that the cascade redox process proposed in the formation of $\mathbf{2}$ from rhodium(I) salts occurs prior to metal-carbene bond formation. This hypothesis is further supported by the fact that metalation in the absence of KI proceeded sluggishly, while replacing $\mathrm{KI}$ by molecular $\mathrm{I}_{2}$ had no negative effect on the yield.

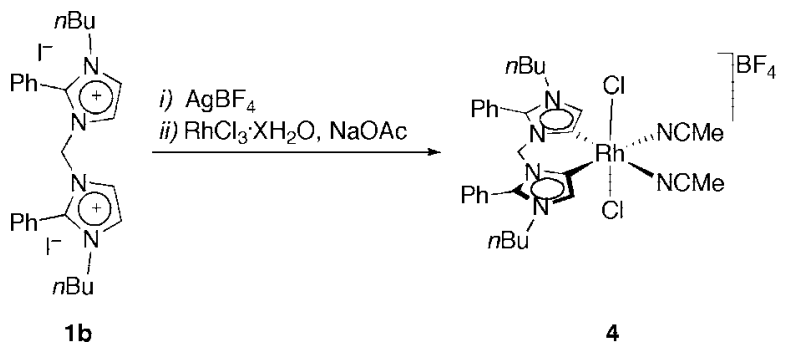

All dimeric complexes $\mathbf{2}$ are stable toward air and moisture, and they are moderately soluble in chlorinated solvents and THF. The ${ }^{1} \mathrm{H}$ NMR spectrum of $\mathbf{2} \mathbf{b}$ in $\mathrm{CD}_{2} \mathrm{Cl}_{2}$ is illustrative and shows the presence of three signals for the methylene group in a 10: 1:1 ratio as well-separated $\mathrm{AB}$ doublets between 5.5 and 6.5 $\mathrm{ppm}$. This points to the presence of different isomers, perhaps due to the different conformations that can be adopted by the dimer 2, including a syn and an eclipsed orientation of the nonbridging iodides. In the ${ }^{13} \mathrm{C}\left\{{ }^{1} \mathrm{H}\right\}$ NMR spectrum of $\mathbf{2} \mathbf{b}$ only the signals of the major isomer are well resolved. Two sets of signals are observed in a 1:1 ratio, thus suggesting a dissymmetric arrangement of the two heterocycles of the dicarbene ligand. The largest shift difference has been noted for the rhodium-bound carbene nuclei $\left(\delta_{\mathrm{C}} 139.4\right.$ and 137.2). These signals appear as doublets, each with a characteristic coupling constant, ${ }^{1} J_{\mathrm{CRh}}=42.0 \mathrm{~Hz}$.

While NMR spectroscopic analyses did not allow us to conclusively determine the structure of complexes $\mathbf{2}$, elemental analyses were in good agreement with a compound of general formula $\left[\mathrm{RhI}_{3} \text { (dicarbene) }\right]_{n}$. A crystal structure analysis of $\mathbf{2 b}$ provided unambiguous evidence for the anticipated dimeric arrangement (Figure 1). The two rhodium centers are both coordinated to a chelating $\mathrm{C} 4$-bound dicarbene ligand. The distorted octahedral geometry around rhodium is completed by one $\mu^{1}$-coordinating and three $\mu^{2}$-bridging iodides. The $\mu^{1}$-bound iodides are in mutual cis position, thus implying an apparent $C_{s}$ symmetry in the solid state. As observed in related palladium chemistry, ${ }^{5}$ the metal-carbon bond lengths are not significantly different from those of C2-bound imidazolylidene complexes. The $\mathrm{Rh}-\mathrm{I}$ bonds that are trans to carbenes ( $\mathrm{Rh}-\mathrm{I} 1$ and $\mathrm{Rh}-\mathrm{I} 2)$ are significantly longer than the $\mathrm{Rh}-\mathrm{I} 3$ bond trans to the nonbridging iodide, thus reflecting the high trans influence of C4-bound carbene ligands.

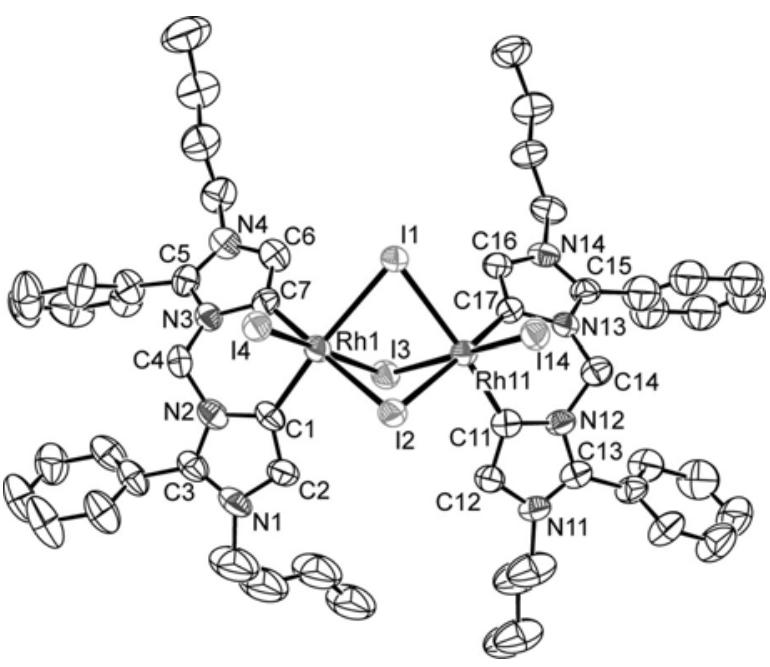

Figure 1. ORTEP representation of the cationic portion of complex 2b $(50 \%$ probability level, cocrystallized solvent molecules and the disordered iodide anion omitted for clarity).

Table 1. Selected Bond Lengths (̊̊) and Angles (deg) for Complex 2b

\begin{tabular}{llll}
\hline \multicolumn{4}{c}{ Bond Lengths } \\
\hline Rh1-C1 & $1.979(11)$ & Rh2-C28 & $2.003(11)$ \\
Rh1-C7 & $1.998(12)$ & Rh2-C34 & $1.991(11)$ \\
Rh1-I1 & $2.8130(11)$ & Rh2-I1 & $2.8140(10)$ \\
Rh1-I2 & $2.7578(11)$ & Rh2-I2 & $2.7664(11)$ \\
Rh1-I3 & $2.6524(11)$ & Rh2-I3 & $2.6463(11)$ \\
Rh1-I5 & $2.6585(11)$ & Rh2-I4 & $2.6792(12)$ \\
C1-C2 & $1.369(17)$ & C28-C29 & $1.373(16)$ \\
C6-C7 & $1.371(17)$ & C33-C34 & $1.368(15)$
\end{tabular}

\begin{tabular}{lrcr} 
& \multicolumn{3}{c}{ Bond Angles } \\
$\mathrm{C} 1-\mathrm{Rh} 1-\mathrm{C} 7$ & $88.8(5)$ & $\mathrm{C} 28-\mathrm{Rh} 2-\mathrm{C} 34$ & $88.0(4)$ \\
$\mathrm{C} 1-\mathrm{Rh} 1-\mathrm{I} 1$ & $173.4(4)$ & $\mathrm{C} 28-\mathrm{Rh} 2-\mathrm{I} 1$ & $173.9(3)$ \\
$\mathrm{C} 1-\mathrm{Rh} 1-\mathrm{I} 2$ & $92.0(4)$ & $\mathrm{C} 28-\mathrm{Rh} 2-\mathrm{I} 2$ & $92.9(3)$ \\
$\mathrm{C} 1-\mathrm{Rh} 1-\mathrm{I} 3$ & $90.3(4)$ & $\mathrm{C} 28-\mathrm{Rh} 2-\mathrm{I} 3$ & $90.6(3)$ \\
$\mathrm{C} 1-\mathrm{Rh} 1-\mathrm{I} 5$ & $91.1(4)$ & $\mathrm{C} 28-\mathrm{Rh} 2-\mathrm{I} 4$ & $91.5(3)$ \\
$\mathrm{I} 1-\mathrm{Rh} 1-\mathrm{I} 2$ & $85.60(3)$ & $\mathrm{I} 1-\mathrm{Rh} 2-\mathrm{I} 2$ & $85.41(3)$ \\
$\mathrm{I} 1-\mathrm{Rh} 1-\mathrm{I} 3$ & $83.40(3)$ & $\mathrm{I} 1-\mathrm{Rh} 2-\mathrm{I} 3$ & $83.49(3)$ \\
$\mathrm{I} 2-\mathrm{Rh} 1-\mathrm{I} 3$ & $84.48(3)$ & $\mathrm{I} 2-\mathrm{Rh} 2-\mathrm{I} 3$ & $84.42(3)$
\end{tabular}

Complexes $\mathbf{2} \mathbf{a}-\mathbf{e}$ are unstable in coordinating solvents. In the presence of even weak ligands such as $\mathrm{MeCN}$, instantaneous cleavage of the dimeric structure gave the monometallic complexes $3 \mathbf{a}-\mathbf{e}$. The ${ }^{1} \mathrm{H}$ and ${ }^{13} \mathrm{C}$ NMR spectra of complexes $3 \mathbf{a}-\mathbf{e}$ in $\mathrm{CD}_{3} \mathrm{CN}$ are significantly simpler than those of the corresponding dimers 2 and reveal a single set of signals. The ${ }^{1} \mathrm{H}$ NMR spectrum of $\mathbf{3 a}$, for example, shows a sharp singlet for the protons of the heterocycle $\left(\delta_{\mathrm{H}} 6.90\right)$ and also for the methylene group $\left(\delta_{\mathrm{H}} 6.19\right)$. This is in good agreement with a $C_{2 v}$-symmetric structure comprising a flexible metallacycle that undergoes rapid inversion of its boat-type conformation. In the ${ }^{13} \mathrm{C}\left\{{ }^{1} \mathrm{H}\right\}$ NMR spectrum, a doublet for the metal-bound carbon is observed at $\delta_{\mathrm{C}} 130.0\left({ }^{1} J_{\mathrm{CRh}}=38.0 \mathrm{~Hz}\right)$. The related rhodium(III) complexes $\mathbf{3 f}$ and $\mathbf{3 g}$ comprising C2-bound dicarbene ligands have been prepared for comparative purposes and according to an established procedure (Scheme 1). ${ }^{22}$

Solid State Structures. Unambiguous structural information on complexes 3a-f was obtained from X-ray analyses (Figure 2). Selected bond lengths and angles are listed in Table 2. In all structures, the rhodium atom is in a slightly distorted octahedral geometry that is defined by the cis-chelating dicarbene, two MeCN molecules, and two iodides in mutual trans position. Such an arrangement may be surmised from the

(22) Poyatos, M.; Sanaú, M.; Peris, E. Inorg. Chem. 2003, 42, 2572. 


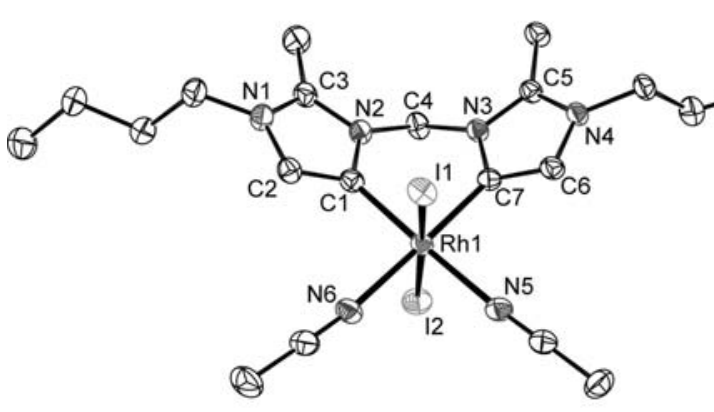

c)

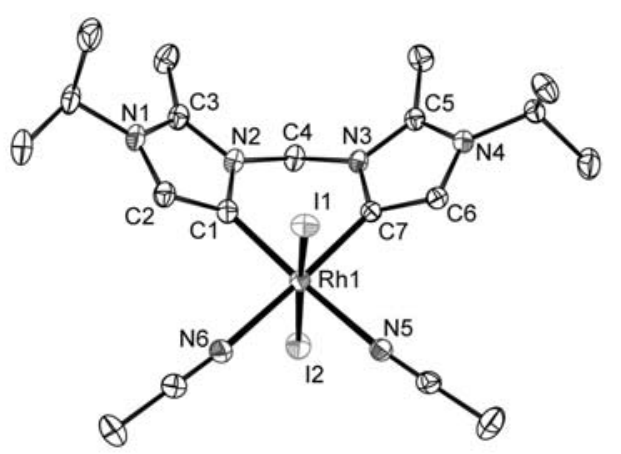

d)

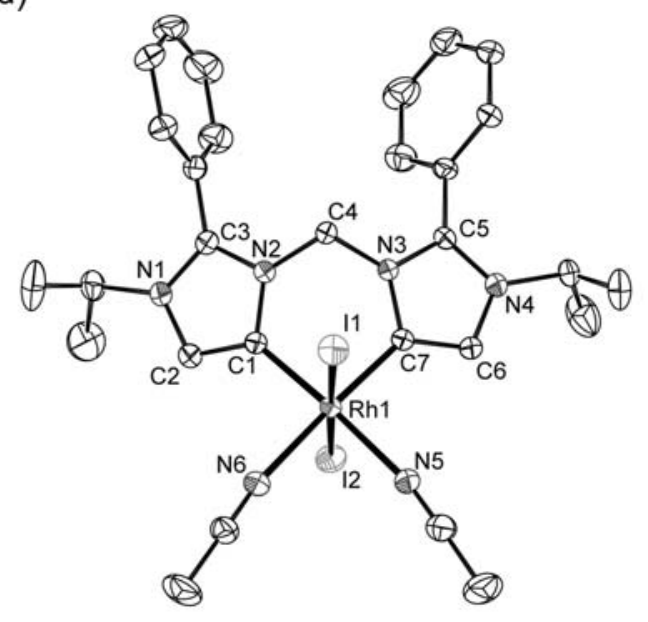

e)

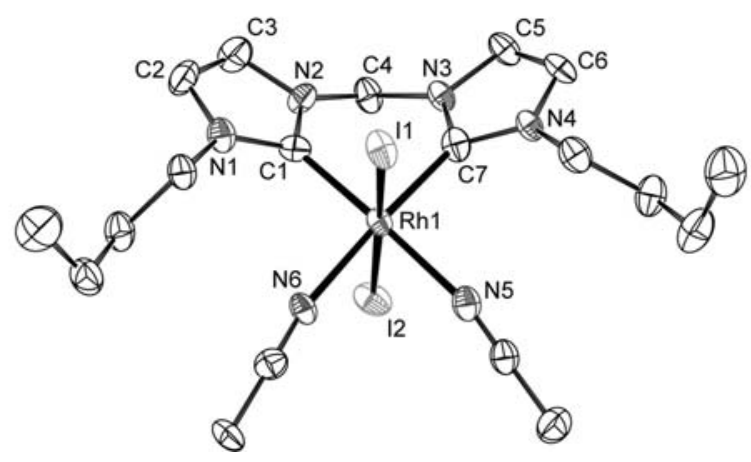

Figure 2. ORTEP representation of the cations of the C4-bound carbene complexs 3a (a), 3b (b), 3c (c), and 3d (d) and of the C2-bound dicarbene complex $\mathbf{3 f}$ (e). Ellipsoids are drawn at the 50\% probability level (3c at 30\%); hydrogen atoms and cocrystallized solvent molecules and $I_{2}$ (for $3 \mathbf{c}$ ) have been omitted for clarity.

different trans influence of the ligands (carbene $>\mathrm{I}^{-}>\mathrm{MeCN}$ ) and indicates the formation of the thermodynamically most stable products. The average $\mathrm{Rh}-\mathrm{C}$ bond distance in the $\mathrm{C} 4-$ bound dicarbene complexes is 1.985(4) $\AA$ and does not differ significantly from the $\mathrm{Rh}-\mathrm{C}$ bond length in similar $\mathrm{C} 2$-bound rhodium(III) dicarbenes such as complex 3f. The $\mathrm{Rh}-\mathrm{N}_{\mathrm{MeCN}}$ distances of complexes $\mathbf{3 a}-\mathbf{d}$ are in the range $2.10-2.12 \AA$ and hence only slightly longer than those in the $\mathrm{C} 2$-bound systems (Rh-N 2.07-2.11 $\AA$; cf. 3f and ref 22). This similarity may be a superimposition of the higher trans influence of the C4-bound carbene and the smaller steric shielding due to the more remote location of the wingtip substituents (cf. the different bond angles around Rh). Notably, the heterocyclic $\mathrm{C}-\mathrm{C}$ bond in $\mathbf{3 a}-\mathbf{d}$ is predominantly conjugated (average $\mathrm{C}-\mathrm{C} 1.360$ (5)
$\AA$ ), while in the $\mathrm{C} 2$-bound analogues, this bond resembles rather a localized olefinic $C=C$ bond $(1.33 \AA)$. Similarly long $C-C$ bonds were also observed in related $\mathrm{C} 4$-bound carbene palladium complexes. ${ }^{5}$ This may be due to a $\mathrm{C}-\mathrm{C}-\mathrm{Rh}$ three-center four-electron interaction as the principal contribution for metal bonding, thus pointing to a weak $\pi$-electron delocalization within the heterocycle. ${ }^{7 \mathrm{~b}}$ Interestingly, complex $\mathbf{3 c}$ cocrystallized with one molecule of $\mathrm{I}_{2}$, which provides additional support for the proposed cascade mechanism proposed for the formation of these rhodium(III) complexes from $[\mathrm{RhCl}(\mathrm{cod})]_{2}$ (vide supra).

Ligand Substitution Reactions. The dimer $\mathbf{2}$ is a useful starting material for investigating the coordination properties of the rhodium center in a C4-bound dicarbene ligand environment. For example, treatment of complex $\mathbf{2 b}$ with $\mathrm{PPh}_{3}$ afforded 
Table 2. Selected Bond Lengths ( $\AA$ ) and Angles (deg) for Complexes $3 a-d$ and $3 f$

\begin{tabular}{|c|c|c|c|c|c|}
\hline & $3 \mathbf{a}$ & $3 \mathbf{b}$ & $3 c$ & 3d & $3 f$ \\
\hline $\mathrm{Rh} 1-\mathrm{C} 1$ & $1.988(2)$ & $1.983(3)$ & $1.976(3)$ & $1.989(2)$ & $1.994(4)$ \\
\hline $\mathrm{Rh} 1-\mathrm{C} 7$ & $1.987(2)$ & $1.981(3)$ & $1.988(3)$ & $1.985(2)$ & $1.988(4)$ \\
\hline Rh1-N5 & $2.115(2)$ & $2.109(3)$ & $2.102(3)$ & $2.118(2)$ & $2.109(4)$ \\
\hline $\mathrm{Rh} 1-\mathrm{I} 1$ & $2.6809(3)$ & $2.6510(3)$ & $2.6671(3)$ & $2.6874(3)$ & $2.6665(5)$ \\
\hline Rh1-I2 & $2.6647(3)$ & $2.6714(3)$ & $2.6822(3)$ & $2.6523(3)$ & $2.6746(5)$ \\
\hline $\mathrm{C} 1-\mathrm{C} 2$ & $1.359(3)$ & $1.358(5)$ & $1.367(4)$ & $1.361(3)$ & \\
\hline $\mathrm{C} 6-\mathrm{C} 7$ & $1.357(3)$ & $1.364(4)$ & $1.350(4)$ & $1.361(4)$ & \\
\hline $\mathrm{C} 1-\mathrm{Rh} 1-\mathrm{N} 6$ & $89.93(9)$ & $91.38(11)$ & $89.86(12)$ & $92.09(10)$ & $95.55(16)$ \\
\hline N6-Rh1-N5 & $91.84(8)$ & $88.14(10)$ & $92.82(10)$ & $85.43(9)$ & $82.96(14)$ \\
\hline N5-Rh1-C7 & $89.62(8)$ & $92.27(11)$ & $89.92(11)$ & $92.35(10)$ & $94.24(16)$ \\
\hline I1-Rh1-I2 & $176.828(9)$ & $177.613(12)$ & $175.593(12)$ & $177.390(9)$ & $177.20(2)$ \\
\hline
\end{tabular}

Scheme 2. Reactivity of Dinuclear Rhodium(III) Complexes toward Phosphines ${ }^{a}$
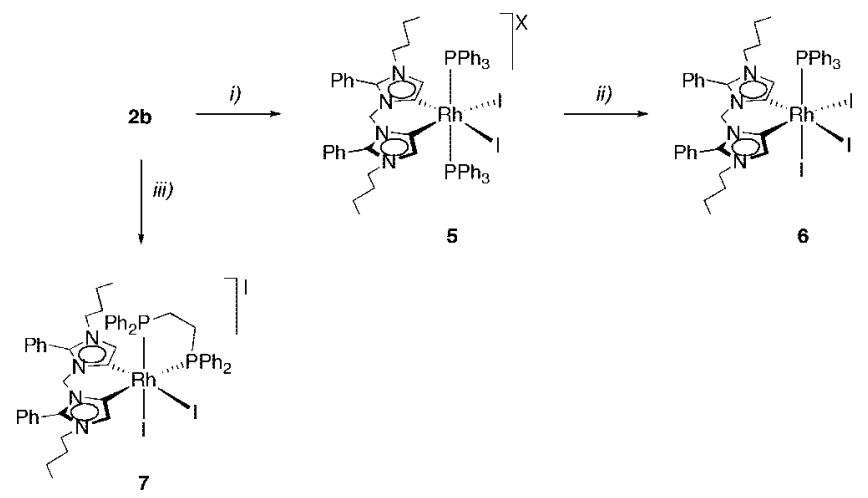

${ }^{a}$ Reagents and conditions: (i) excess $\mathrm{PPh}_{3}, \mathrm{CH}_{2} \mathrm{Cl}_{2}$; (ii) $\mathrm{SiO}_{2}, \mathrm{CH}_{2} \mathrm{Cl}_{2}$; (iii) dppe, $\mathrm{CH}_{2} \mathrm{Cl}_{2}$.

initially the bis(phosphine) complex 5 (Scheme 2). Complex 5 is stable as solid in air, while in solution slow decomposition was observed. The ${ }^{1} \mathrm{H}$ and ${ }^{31} \mathrm{P}$ NMR spectra of 5 in $\mathrm{CD}_{2} \mathrm{Cl}_{2}$ showed one major and two minor sets of signals, implying the existence of three isomers in $\mathrm{CD}_{2} \mathrm{Cl}_{2}$ solution. Again the $\mathrm{CH}_{2}$ group between the two heterocycles is diagnostic for determining the ratio of these isomers (12:1:1). A similar product distribution is also indicated by ${ }^{31} \mathrm{P} \mathrm{NMR}$, showing a resonance for the major isomer at $\delta_{\mathrm{P}} 12.5\left({ }^{1} J_{\mathrm{PRh}}=89.7 \mathrm{~Hz}\right)$ and overlapping resonances for the minor species at $\delta_{\mathrm{P}} 15.3\left({ }^{1} J_{\mathrm{PRh}}=93.5 \mathrm{~Hz}\right)$. Integration and chemical shift values are in agreement with two phosphines coordinated to the metal center in a symmetric arrangement. While electronic arguments would favor a trans conformation of the phosphines (trans effect carbene $>$ phosphine $>$ iodide), steric repulsion with the twisted carbene heterocycles may force the phosphines into an arrangement in which the phosphines are coplanar with the carbenes and, therefore, the iodides in mutual trans position.

In contrast to the measurements in $\mathrm{CD}_{2} \mathrm{Cl}_{2}$, the NMR spectra in $\mathrm{CD}_{3} \mathrm{CN}$ solution showed several sets of signals and in addition also the presence of free $\mathrm{PPh}_{3}$. This indicates relatively easy solvolysis of complex 5 and concomitant release of $\mathrm{PPh}_{3}$. Purification of the diphosphine complex $\mathbf{5}$ by silica gel chromatography indeed induced the clean dissociation of one $\mathrm{PPh}_{3}$ ligand and gave the monophosphine complex 6 . The ${ }^{1} \mathrm{H}$ NMR spectrum indicates the presence of two isomers due to the appearance of two AX sets centered at $\delta_{\mathrm{H}} 6.22$ and 5.39 and at $\delta_{\mathrm{H}} 5.94$ and 5.07 , respectively $\left({ }^{2} J_{\mathrm{HH}}=13.2 \mathrm{~Hz}\right)$. Temperaturedependent measurements revealed an equilibrium between the two isomers with the low-field pattern belonging to the exothermic product. Analyses according to the van't Hoff equation gave a reaction enthalpy of $\Delta H^{\circ}=+24.5( \pm 0.1) \mathrm{kJ}$ $\mathrm{mol}^{-1}$ and an entropy change of $\Delta S^{\circ}=-84.2( \pm 0.3) \mathrm{J} \mathrm{K}^{-1}$ $\mathrm{mol}^{-1}$ within the $263-333 \mathrm{~K}$ temperature range. The large entropy term makes an intramolecular process unlikely and puts forward a dissociation of iodide from neutral $\mathbf{6}$ and formation of the ionic complex $\mathbf{6}^{\prime}$ at low temperature (eq 2).
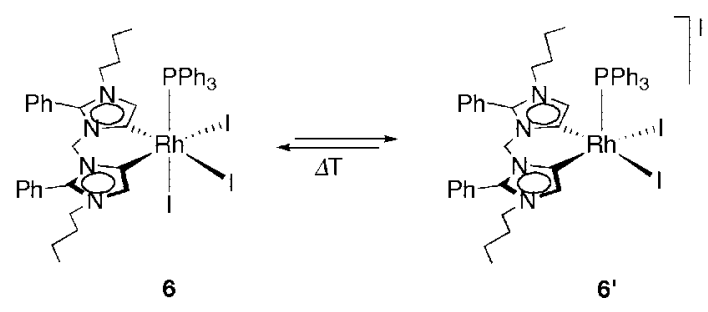

In such a model, the negative entropy term reflects the increased ionic strength in $\mathbf{6}^{\prime}$, which is accompanied by a more pronounced solvatization of the two ions in $\mathbf{6}^{\prime}$ as compared to the neutral species $\mathbf{6}^{23}$ The assignment of ionic $\mathbf{6}^{\prime}$ as the exothermic product is further supported by the results obtained from adding $\mathrm{KPF}_{6}$ to a solution of $\mathbf{6}$. Only the signals of $\mathbf{6}^{\prime}$ (albeit with a different counterion) were observed, while the resonances attributed to $\mathbf{6}$ disappeared completely. The equilibrium between $\mathbf{6}$ and $\mathbf{6}^{\prime}$ probably arises as a consequence of the steric congestion imposed by the boat-type metallacycle and the bulky $\mathrm{PPh}_{3}$ ligand. This is in agreement with the large $\mathrm{P}-\mathrm{Rh}$ coupling constant $\left({ }^{1} J_{\mathrm{PRh}}=112.8 \mathrm{~Hz}\right)$ and hence a weak bonding of the trans-located ligand. ${ }^{24}$ In addition, the strong donor properties of the $\mathrm{C} 4$-bound dicarbene ligand facilitate anion dissociation in $\mathbf{6}$.

Coordination of two phosphines to the $\mathrm{Rh}$ (dicarbene) fragment is more stable when a chelating diphosphine is used rather than an excess of $\mathrm{PPh}_{3}$. For example, the monomeric complex $\mathbf{7}$ was obtained in good yields upon treating complex $\mathbf{2 b}$ with diphenylphosphinoethane (dppe) in $\mathrm{CH}_{2} \mathrm{Cl}_{2}$. The ${ }^{1} \mathrm{H}$ NMR indicates symmetry-related heterocycles. Similarly, a single resonance is seen in the ${ }^{31} \mathrm{P} \mathrm{NMR}\left(\delta_{\mathrm{P}} 21.4,{ }^{1} J_{\mathrm{RhP}}=75.1 \mathrm{~Hz}\right)$, thus implying a $C_{2 v}$-symmetric structure in solution. In the solid state, however, $C_{1}$ symmetry was established with an all-trans ligand coordination (Figure 3 ). In the crystallized $\Lambda$-form, the $\mathrm{Rh}-\mathrm{I}$ bond trans to phosphine is unexpectedly longer $(\mathrm{Rh}-\mathrm{I} 2$ 2.721(1) $\AA$ ) than the one trans to the C4-bound carbene ( $\mathrm{Rh}-\mathrm{I} 1$ 2.636(1) ̊).

(23) (a) Marcus Y. Ion Solvation; Wiley: Chichester; 1985. This concept is also known in biological systems, see for example:(b) Dill, K. A.; Truskett, T. M.; Vlachy, V.; Hribar-Lee, B. Annu. Rev. Biophys. Biomol. Struct. 2005, 34,173 .

(24) Meek, D. W.; Mazanec, T. J. Acc. Chem. Res. 1981, 14, 266. 


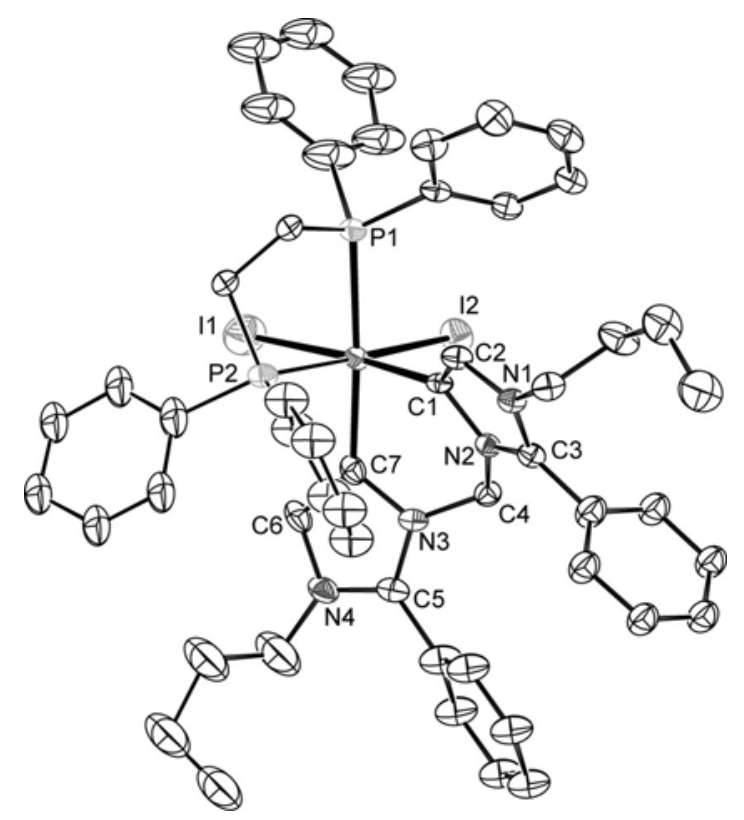

Figure 3. ORTEP representation of complex 7 (30\% probability level, hydrogen atoms, the cocrystallized ether molecules, and the $\mathrm{I}^{-}$anion omitted for clarity; only one of the two disordered positions of the $\mathrm{CH}_{2} \mathrm{CH}_{2} \mathrm{PPh}_{2}$ moiety of the dppe ligand is shown). Selected bond lengths ( $\AA$ ): Rh1-C1 2.031(9), Rh1-C7 2.050(10), Rh1-I1 2.6359(12), Rh1-I2 2.7209(10), Rh1-P1 2.357(2), Rh1-P2 2.237(13), C1-C2 1.370(12), C6-C7 1.352(13). Selected bond angles (deg): C1-Rh1-C7 88.3(4),C1-Rh1-I1 175.9(2), C1-Rh1-I2 92.4(2), C1-Rh1-P1 92.6(2), C1-Rh1-P2 94.9(3), C7-Rh1-P1 176.4(2), C7-Rh1-P2 90.1(4), P1-Rh1-P2 86.7(3), I1-Rh1-I2 89.85(4).

Catalytic Transfer Hydrogenation. The versatility of complexes $\mathbf{2}$ in coordinating various ligands was further exploited in hydrogen transfer catalysis. ${ }^{25}$ The reduction of benzophenone to diphenyl methanol in $i \mathrm{PrOH}$ was used as a model reaction for probing the catalytic activity of the rhodium(III) complexes (eq 3 and Table 3). A first screening aimed at optimizing reaction conditions was carried out with the dimeric complex 2b as catalyst. In a typical reaction, the active catalyst was formed by heating a mixture of $\mathbf{2 b}$ in basic $i \mathrm{PrOH}$ for $10 \mathrm{~min}$ prior to substrate addition. When the substrate was added first, the catalytic activity was low. Catalyst manipulation does not need particular precautions, and transfer hydrogenations were generally performed in air and without solvent pretreatment. The base was added as a concentrated aqueous solution, which underlines the stability of the rhodium catalyst system toward moisture. Identical conversions were obtained in a comparative experiment using $\mathrm{KO} t \mathrm{Bu}$ dissolved in $i \mathrm{PrOH}$ as base, thus avoiding the addition of traces of water (entries 2, 3). A KarlFischer titration of the $i \mathrm{PrOH}$ solvent indicated a water content of $0.5 \%$, which corresponds to $25 \mu \mathrm{L}$ in the $5 \mathrm{~mL}$ volume used for standard reactions. Notably, addition of deliberate amounts of water $(0.2 \mathrm{~mL})$ did slow down the reaction slightly (entry 4). Hence, water at low concentration $(0.5-1 \%)$ does not affect the catalyst, while higher concentrations $(>5 \%)$ reduce its activity. Much more detrimental is, however, the presence of $\mathrm{MeCN}$ (entry 5). Apparently, formation of complexes 3 is faster

(25) (a) Klomp, D.; Hanefeld, U.; Peters, J. A. In The Handbook of Homogeneous Hydrogenation; de Vries, J. G., Elsevier, C. J., Eds.; WileyVCH: Weinheim, 2007, p 585. (b) Samec, J. S. M.; Bäckvall, J-E.; Andersson, P. G.; Brandt, P. Chem. Soc. Rev. 2006, 35, 237. (c) Gladiali, S.; Alberico, E. Chem. Soc. Rev. 2006, 35, 226. (d) Clapham, S. E.; Hadzovic, A.; Morris, R. H. Coord. Chem. Rev. 2004, 248, 2201.
Table 3. Catalytic Transfer Hydrogenation of Benzophenone with Rhodium(III) Dicarbene Complexes ${ }^{a}$

\begin{tabular}{|c|c|c|c|c|c|}
\hline entry & catalyst & $\mathrm{mol} \%$ & time $(\mathrm{h})$ & conversion $(\%)^{b}$ & TON \\
\hline 1 & & & $0.5 / 16$ & $0.6 / 11$ & \\
\hline 2 & $2 b$ & 0.5 & $0.5 / 2$ & $54 / 97$ & 97 \\
\hline $3^{c}$ & $2 b$ & 0.5 & $0.5 / 2$ & $47 / 94$ & 94 \\
\hline $4^{d}$ & $2 b$ & 0.5 & $0.5 / 2$ & $36 / 73$ & 73 \\
\hline $5^{e}$ & $2 b$ & 0.5 & $0.5 / 2$ & $5 / 14$ & 14 \\
\hline 6 & $2 \mathbf{a}$ & 0.5 & $0.5 / 2$ & $45 / 82$ & 82 \\
\hline 7 & $2 c$ & 0.5 & $0.5 / 2$ & $44 / 84$ & 84 \\
\hline 8 & 2d & 0.5 & $0.5 / 2$ & $48 / 87$ & 87 \\
\hline 9 & $2 e$ & 0.5 & $0.5 / 2$ & 60/91 & 91 \\
\hline 10 & $3 \mathbf{a}$ & 0.5 & $0.5 / 2$ & $53 / 91$ & 91 \\
\hline 11 & $3 f$ & 1 & $0.5 / 2$ & $5 / 17$ & 17 \\
\hline 12 & $3 g$ & 1 & $0.5 / 2$ & $3 / 6$ & 6 \\
\hline 13 & 4 & 1 & $0.5 / 2$ & 73/97 & 97 \\
\hline 14 & 4 & 0.1 & $0.5 / 40$ & $10 / 33$ & 330 \\
\hline
\end{tabular}

${ }^{a}$ General conditions: $1 \mathrm{mmol}$ of benzophenone, $5 \mathrm{~mL}$ of $i \mathrm{PrOH}, 100$ $\mu \mathrm{mol}$ of base (substrate/base 10:1), reflux temperature. ${ }^{b}$ Average of at least two runs. ${ }^{c} \mathrm{KO} t \mathrm{Bu}$ used as base. ${ }^{d}$ Addition of $\mathrm{H}_{2} \mathrm{O}(0.2 \mathrm{~mL})$. ${ }^{e}$ Addition of $\mathrm{MeCN}(0.2 \mathrm{~mL})$.

Table 4. Catalytic Transfer Hydrogenation of Ketones and Imines with the Dicarbene Complex $2 \mathbf{b}^{a}$

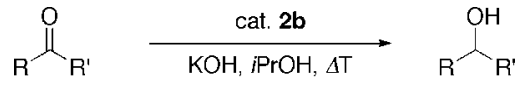

\begin{tabular}{clccc}
\hline entry & \multicolumn{1}{c}{ ketone } & cat $\mathbf{2 b}(\mathrm{mol} \%)$ & time $(\mathrm{h})$ & conversion $(\%)$ \\
\hline 1 & benzophenone & 0.5 & $0.5 / 2$ & $54 / 97$ \\
2 & acetophenone & 0.5 & $0.5 / 2$ & $66 / 93$ \\
3 & propiophenone & 0.5 & $0.5 / 2$ & $32 / 74$ \\
4 & 3,3,5,5-Me 4 -cy=O & 0.5 & $0.5 / 2$ & $18 / 40$ \\
5 & 2-octanone & 0.5 & $0.5 / 2$ & $17 / 57$ \\
6 & 3-octanone & 0.5 & $0.5 / 2$ & $12 / 40$ \\
7 & Ph-CH=NMe & 0.5 & 2 & $<2$
\end{tabular}

${ }^{a}$ General conditions: $1 \mathrm{mmol}$ of ketone, $5 \mathrm{~mL}$ of $i \mathrm{PrOH}, 100 \mu \mathrm{mol}$ of base (substrate/base 10:1), reflux temperature.

and competitive to alkoxide/ketone coordination to $\mathbf{2}$. An excess of $\mathrm{MeCN}$ effectively poisons the catalyst, while equimolar concentrations as in complex 3a do not reduce the catalytic activity (entry 10).

The substitution pattern on the dicarbene ligand has a relatively small influence on the catalytic activity. From our limited variation in catalyst design, no clear trend can be deduced and the differences in activity are small (entries 2, $6-9)$. The turnover frequency at $50 \%$ conversion $\left(\mathrm{TOF}_{50}\right)$ is $100 \pm 20 \mathrm{~h}^{-1}$ for all catalyst precursors $\mathbf{2 a}-\mathbf{e}$. Dimer cleavage in $\mathbf{2}$ seems to be fast also during catalysis, and conversions are identical when starting from the dimer $\mathbf{2}$ or the corresponding monometallic complexes (e.g., 3a, entry 10). However, rhodium coordination via the $\mathrm{C} 4$ position is critical for inducing catalytic activity. The rhodium complexes $\mathbf{3 f}$ and $\mathbf{3 g}$ comprising a $\mathbf{C} 2-$ bound dicarbene ligand are significantly less active catalysts than the C4-bound complexes and give only poor conversions (entries 11, 12). Apparently, the stronger donor properties of the C4-bound carbene ligands produce a more electron-rich rhodium center, which is supposed to accelerate in particular the product release step in the catalytic cycle. ${ }^{25}$

The relevance of high electron density at the metal center is further strengthened by the catalytic activity of the chloro complex 4 . This complex is the most active catalyst of the series. 
Transfer hydrogenation is essentially complete in $1 \mathrm{~h}$, and the $\mathrm{TOF}_{50}$ is raised to $300 \mathrm{~h}^{-1}$ at $1 \mathrm{~mol} \%$ catalyst loading (entry 13). ${ }^{26}$ Lowering the catalyst loading gave only incomplete conversions, and the noncatalyzed background reduction becomes a competitive process (entry 14). Perhaps, catalyst deactivation due to the higher relative water concentration may become relevant at such low rhodium levels.

Different ketones are efficiently hydrogenated with these new dicarbene rhodium catalysts. Acetophenone reduction takes place at slightly faster rates than benzophenone hydrogenation (Table 4, entries 1, 2). Larger alkyl groups are also tolerated. Propiophenone, for example, is converted only a little slower than acetophenone and transfer hydrogenation is complete within $4 \mathrm{~h}$ (entry 3). Aliphatic methylketones require longer reaction times than their aryl analogues. This effect is even more pronounced for sterically demanding substrates such as 3-octanone and 3,3,5,5-tetramethylcyclohexanone, for which hydrogenation does not reach completion even after $16 \mathrm{~h}$ (entries 4-6). Imines appear to poison the catalytically active species. When using $N$-methylbenzylimine, no amine formation was observed (entry 7). Instead, traces of benzyl alcohol were initially detected, probably originating from hydrolysis of the imine and subsequent transfer hydrogenation of the corresponding aldehyde. ${ }^{27}$ However, this reaction does not progress, and even after prolonged reaction time, more than $95 \%$ of imine was present in the reaction mixture.

\section{Conclusions}

Direct metalation of C2-substituted diimidazolium salts provides access to chelating rhodium dicarbene complexes in which the heterocyclic carbenes are bound unusually via the $\mathrm{C} 4$ carbon. This bonding mode increases the electron density at the metal center, thus invoking new reactivity patterns. The exceptionally strong donor properties of such C4-bound carbenes have been utilized for the development of new rhodium catalysts for the transfer hydrogenation of ketones. The catalytic activity of the rhodium center critically depends on the carbene bonding mode and requires $\mathrm{C} 4$-bound carbenes, whereas $\mathrm{C} 2$-bound analogues are essentially inactive. These results are another indication for the high impact of C4-bound carbene ligands in inducing new (catalytic) properties of the coordinated metal center. Further investigations along these lines are currently in progress in our laboratories, in particular with the aim of catalytically activating otherwise unreactive bonds.

\section{Experimental Section}

General Comments. The $\mathrm{N}$-alkylated imidazoles, ${ }^{18}$ the ligand precursors $\mathbf{1 c}$ and $\mathbf{1 e},{ }^{5}$ and $[\mathrm{RhCl}(\mathrm{cod})]_{2}{ }^{28}$ were prepared according to literature procedures. All other reagents are commercially available and were used as received. Unless specified otherwise, NMR spectra were recorded at $25{ }^{\circ} \mathrm{C}$ on Bruker spectrometers

(26) Notably, this catalyst activity is still 1 to 2 orders of magnitude lower than that of the most active systems known today. See for examples ref 18b and:(a) Mestroni, G.; Zassinovich, G.; Camus, A.; Martinelli, F. J. Organomet. Chem. 1980, 198, 87. (b) Thoumazet, C.; Melaimi, M.; Ricard, L.; Mathey, F.; Le Floch, P. Organometallics 2003, 22, 1580. (c) Dani, P.; Karlen, T.; Gossage, R. A.; Gladiali, S.; van Koten, G. Angew. Chem., Int. Ed. 2000, 39, 743. (d) Yang, H.; Alvarez, M.; Lugan, N.; Mathieu, R. J. Chem. Soc., Chem. Commun. 1995, 1721. (e) For a reverse reaction, see:

(27) Fujita, K.; Li, Z.; Ozeki, N.; Yamaguchi, R. Tetrahedron Lett. 2003, 44, 2687.

(28) Crabtree, R. H.; Morehouse, S. M.; Quirk, J. M. Inorg. Synth. 1986, $24,173$. operating at 400 or $500 \mathrm{MHz}\left({ }^{1} \mathrm{H}\right.$ NMR), 100 or $125 \mathrm{MHz}\left({ }^{13} \mathrm{C}\right.$ $\mathrm{NMR})$, and $162 \mathrm{MHz}\left({ }^{31} \mathrm{P} \mathrm{NMR}\right)$, respectively. Chemical shifts $(\delta$ in ppm, coupling constants $J$ in $\mathrm{Hz}$ ) were referenced to external $\mathrm{SiMe}_{4}\left({ }^{1} \mathrm{H},{ }^{13} \mathrm{C}\right)$ or $\mathrm{H}_{3} \mathrm{PO}_{4}\left({ }^{31} \mathrm{P}\right)$. Assignments are based on homoand heteronuclear shift correlation spectroscopy. Elemental analyses were performed by the Microanalytical Laboratory of Ilse Beetz (Kronach, Germany).

General Procedure for the Synthesis of Diimidazolium Ligand Precursors 1a-e. A solution of the appropriate 1,2disubstituted imidazole $(20 \mathrm{mmol})$ and $\mathrm{CH}_{2} \mathrm{I}_{2}(2.67 \mathrm{~g}, 10 \mathrm{mmol})$ was stirred in toluene $(20 \mathrm{~mL})$ at reflux for $24 \mathrm{~h}$. The formed precipitate was collected by filtration and recrystallized from $\mathrm{MeOH} /$ $\mathrm{Et}_{2} \mathrm{O}$ at $-20{ }^{\circ} \mathrm{C}$.

$\boldsymbol{N}, \boldsymbol{N}$-Methylenedi( $\boldsymbol{N}^{\prime}$ - $\boldsymbol{n}$-butyl-2-methyl)imidazolium diiodide (1a):. white solid (3.8 g, 70\%). ${ }^{1} \mathrm{H}$ NMR (DMSO- $d_{6}, 400 \mathrm{MHz}$ ): $\delta 7.92\left(\mathrm{~d}, 2 \mathrm{H},{ }^{3} J_{\mathrm{HH}}=2.2 \mathrm{~Hz}, \mathrm{H}_{\mathrm{imi}}\right), 7.83\left(\mathrm{~d}, 2 \mathrm{H},{ }^{3} J_{\mathrm{HH}}=2.2 \mathrm{~Hz}\right.$, $\left.\mathrm{H}_{\mathrm{imi}}\right), 6.57\left(\mathrm{~s}, 2 \mathrm{H}, \mathrm{NCH}_{2} \mathrm{~N}\right), 4.13\left(\mathrm{t}, 4 \mathrm{H},{ }^{3} J_{\mathrm{HH}}=7.4 \mathrm{~Hz}\right.$, $\mathrm{NCH}_{2} \mathrm{CH}_{2} \mathrm{CH}_{2} \mathrm{CH}_{3}$ ), 2.77 (s, $6 \mathrm{H}, \mathrm{CH}_{3}$ ), 1.71 (quintett, $4 \mathrm{H},{ }^{3} J_{\mathrm{HH}}=$ $7.4 \mathrm{~Hz}, \mathrm{NCH}_{2} \mathrm{CH}_{2} \mathrm{CH}_{2} \mathrm{CH}_{3}$ ), 1.30 (sextet, $4 \mathrm{H},{ }^{3} J_{\mathrm{HH}}=7.4 \mathrm{~Hz}$, $\mathrm{NCH}_{2} \mathrm{CH}_{2} \mathrm{CH}_{2} \mathrm{CH}_{3}$ ), $0.90\left(\mathrm{t}, 6 \mathrm{H},{ }^{3} J_{\mathrm{HH}}=7.4 \mathrm{~Hz}, \mathrm{NCH}_{2} \mathrm{CH}_{2} \mathrm{CH}_{2}-\right.$ $\left.\mathrm{CH}_{3}\right) .{ }^{13} \mathrm{C}\left\{{ }^{1} \mathrm{H}\right\}$ NMR (DMSO- $\left.d_{6}, 100 \mathrm{MHz}\right): \delta 145.9\left(\mathrm{C}_{\mathrm{imi}}\right), 122.0$ $\left(\mathrm{C}_{\mathrm{imi}}\right), 121.3\left(\mathrm{C}_{\mathrm{imi}}\right), 56.8\left(\mathrm{NCH}_{2} \mathrm{~N}\right), 47.7\left(\mathrm{NCH}_{2} \mathrm{CH}_{2} \mathrm{CH}_{2} \mathrm{CH}_{3}\right), 30.8$ $\left(\mathrm{NCH}_{2} \mathrm{CH}_{2} \mathrm{CH}_{2} \mathrm{CH}_{3}\right), 18.9\left(\mathrm{NCH}_{2} \mathrm{CH}_{2} \mathrm{CH}_{2} \mathrm{CH}_{3}\right), 13.4\left(\mathrm{NCH}_{2} \mathrm{CH}_{2} \mathrm{CH}_{2}-\right.$ $\left.\mathrm{CH}_{3}\right)$, $10.3\left(\mathrm{CH}_{3}\right)$. Anal. Calcd for $\mathrm{C}_{17} \mathrm{H}_{30} \mathrm{I}_{2} \mathrm{~N}_{4}$ (544.26): C, 37.52; H, 5.56; N, 10.29. Found: C, 37.41; H, 5.44; N, 10.17 .

$\boldsymbol{N}, \boldsymbol{N}$-Methylenedi( $\boldsymbol{N}^{\prime}$ - $\boldsymbol{n}$-butyl-2-phenyl)imidazolium diiodide (1b):. light yellow solid (5.0 g, 75\%). ${ }^{1} \mathrm{H}$ NMR (DMSO- $d_{6}, 400$ $\mathrm{MHz}): \delta 8.06\left(\mathrm{~d}, 2 \mathrm{H},{ }^{3} J_{\mathrm{HH}}=2.2 \mathrm{~Hz}, \mathrm{H}_{\mathrm{imi}}\right), 7.92\left(\mathrm{~d}, 2 \mathrm{H},{ }^{3} J_{\mathrm{HH}}=\right.$ $\left.2.2 \mathrm{~Hz}, \mathrm{H}_{\mathrm{imi}}\right), 7.72\left(\mathrm{~m}, 2 \mathrm{H}, \mathrm{H}_{\text {aryl }}\right), 7.58\left(\mathrm{~m}, 8 \mathrm{H}, \mathrm{H}_{\text {aryl }}\right), 6.29(\mathrm{~s}, 2 \mathrm{H}$, $\left.\mathrm{NCH}_{2} \mathrm{~N}\right), 3.92\left(\mathrm{t}, 4 \mathrm{H},{ }^{3} J_{\mathrm{HH}}=7.4 \mathrm{~Hz}, \mathrm{NCH}_{2} \mathrm{CH}_{2} \mathrm{CH}_{2} \mathrm{CH}_{3}\right), 1.57$ (quintet, $4 \mathrm{H},{ }^{3} \mathrm{~J}_{\mathrm{HH}}=7.4 \mathrm{~Hz}, \mathrm{NCH}_{2} \mathrm{CH}_{2} \mathrm{CH}_{2} \mathrm{CH}_{3}$ ), 1.07 (sextett, $4 \mathrm{H}$, $\left.{ }^{3} J_{\mathrm{HH}}=7.4 \mathrm{~Hz}, \mathrm{NCH}_{2} \mathrm{CH}_{2} \mathrm{CH}_{2} \mathrm{CH}_{3}\right), 0.71\left(\mathrm{t}, 6 \mathrm{H},{ }^{3} J_{\mathrm{HH}}=7.4 \mathrm{~Hz}\right.$, $\left.\mathrm{NCH}_{2} \mathrm{CH}_{2} \mathrm{CH}_{2} \mathrm{CH}_{3}\right) \cdot{ }^{13} \mathrm{C}\left\{{ }^{1} \mathrm{H}\right\} \mathrm{NMR}$ (DMSO-d, $\left.100 \mathrm{MHz}\right): \delta 144.7$ $\left(\mathrm{C}_{\text {imi }}\right), 132.9\left(\mathrm{C}_{\text {aryl }}\right), 130.4\left(\mathrm{C}_{\text {aryl }}\right), 129.7\left(\mathrm{C}_{\text {aryl }}\right), 122.8\left(\mathrm{C}_{\text {imi }}\right), 122.2$ $\left(\mathrm{C}_{\mathrm{imi}}\right), 119.6\left(\mathrm{C}_{\text {aryl }}\right), 57.9\left(\mathrm{NCH}_{2} \mathrm{~N}\right), 48.1\left(\mathrm{NCH}_{2} \mathrm{CH}_{2} \mathrm{CH}_{2} \mathrm{CH}_{3}\right), 30.7$ $\left(\mathrm{NCH}_{2} \mathrm{CH}_{2} \mathrm{CH}_{2} \mathrm{CH}_{3}\right), 18.5\left(\mathrm{NCH}_{2} \mathrm{CH}_{2} \mathrm{CH}_{2} \mathrm{CH}_{3}\right), 13.0\left(\mathrm{NCH}_{2} \mathrm{CH}_{2} \mathrm{CH}_{2^{-}}\right.$ $\mathrm{CH}_{3}$ ). Anal. Calcd for $\mathrm{C}_{27} \mathrm{H}_{34} \mathrm{I}_{2} \mathrm{~N}_{4}$ (668.39): C, 48.52; H, 5.13; N, 8.38. Found: C, 48.33; H, 5.16; N, 8.38.

$N, N$-Methylenedi( $N^{\prime}$-isopropyl-2-phenyl)imidazolium diiodide (1d): light yellow solid (1.5 g, 23\%). ${ }^{1} \mathrm{H}$ NMR (DMSO- $d_{6}, 400$ $\mathrm{MHz}): \delta 8.17\left(\mathrm{~d}, 2 \mathrm{H},{ }^{3} J_{\mathrm{HH}}=2.2 \mathrm{~Hz}, \mathrm{H}_{\mathrm{imi}}\right), 7.91\left(\mathrm{~d}, 2 \mathrm{H},{ }^{3} J_{\mathrm{HH}}=\right.$ $\left.2.2 \mathrm{~Hz}, \mathrm{H}_{\mathrm{imi}}\right), 7.72\left(\mathrm{~m}, 2 \mathrm{H}, \mathrm{H}_{\text {aryl }}\right), 7.60\left(\mathrm{~m}, 8 \mathrm{H}, \mathrm{H}_{\text {aryl }}\right), 6.29$ (s, $2 \mathrm{H}$, $\mathrm{NCH}_{2} \mathrm{~N}$ ), 4.15 (septet, $\left.2 \mathrm{H},{ }^{3} J_{\mathrm{HH}}=6.6 \mathrm{~Hz}, \mathrm{NCH}\left(\mathrm{CH}_{3}\right)_{2}\right), 1.38(\mathrm{~d}$, $\left.12 \mathrm{H},{ }^{3} J_{\mathrm{HH}}=6.6 \mathrm{~Hz}, \mathrm{NCH}\left(\mathrm{CH}_{3}\right)_{2}\right) .{ }^{13} \mathrm{C}\left\{{ }^{1} \mathrm{H}\right\}$ NMR (DMSO- $d_{6}, 100$ $\mathrm{MHz}): \delta 143.7\left(\mathrm{C}_{\mathrm{imi}}\right), 132.9\left(\mathrm{C}_{\text {aryl }}\right), 130.3\left(\mathrm{C}_{\text {aryl }}\right), 129.8\left(\mathrm{C}_{\text {aryl }}\right), 122.9$ $\left(\mathrm{C}_{\text {imi }}\right), 119.7\left(\mathrm{C}_{\mathrm{imi}}\right), 119.4\left(\mathrm{C}_{\text {aryl }}\right), 57.9\left(\mathrm{NCH}_{2} \mathrm{~N}\right), 51.6\left(\mathrm{NCH}\left(\mathrm{CH}_{3}\right)_{2}\right)$, $22.0\left(\mathrm{NCH}\left(\mathrm{CH}_{3}\right)_{2}\right)$. Anal. Calcd for $\mathrm{C}_{25} \mathrm{H}_{30} \mathrm{I}_{2} \mathrm{~N}_{4}(640.06) \times \mathrm{H}_{2} \mathrm{O}$ : C, 45.61; H, 4.90; N, 8.51. Found: C, 45.73; H, 5.06; N, 8.52.

General Procedure for the Synthesis of $\left[(\mu-\mathrm{I})_{3}-\right.$ $\left.\{\text { RhI(dicarbene) }\}_{2}\right] \mathbf{I}(\mathbf{2} \mathbf{a}-\mathbf{e})$. Method A: A mixture of the corresponding diimidazolium salt 1 ( 1 molar equiv), $[\mathrm{RhCl}(\mathrm{cod})]_{2}(0.5$ molar equiv), KI (4 mol equiv), and $\mathrm{NaOAc}$ ( 8 molar equiv) was stirred in $\mathrm{MeCN}$ at reflux temperature for $24 \mathrm{~h}$. After cooling, all volatiles were removed under reduced pressure and the residue was purified by gradient column chromatography. Method B: A mixture of the diimidazolium salt (1 molar equiv), $\left[\mathrm{RhCl}_{3}\left(\mathrm{H}_{2} \mathrm{O}\right)_{x}\right](1$ molar equiv), and $\mathrm{NaOAc}$ ( 8 molar equiv) was refluxed in $\mathrm{MeCN}$ for 24 h. After cooling, all volatiles were removed under reduced pressure and the residue was purified by gradient column chromatography $\left(\mathrm{SiO}_{2} ; \mathrm{CH}_{2} \mathrm{Cl}_{2}\right.$ /acetone, 5:1). The orange fraction was dissolved in a solution of $\mathrm{NaI}$ (10 molar equiv) in acetone and stirred for $24 \mathrm{~h}$. After filtration of the mixture, the volatiles of the filtrate were removed under reduced pressure and subsequently extracted into $\mathrm{CH}_{2} \mathrm{Cl}_{2}$. Evaporation of this solution to dryness gave complex 2.

Synthesis of 2a. According to method A, starting from 1a (272 $\mathrm{mg}, 0.5 \mathrm{mmol}),[\mathrm{RhCl}(\mathrm{cod})]_{2}(123 \mathrm{mg}, 0.25 \mathrm{mmol}), \mathrm{KI}(332 \mathrm{mg}$, 
$2.0 \mathrm{mmol}$ ), and $\mathrm{NaOAc}(328 \mathrm{mg}, 4.0 \mathrm{mmol})$. Gradient column chromatography $\left(\mathrm{SiO}_{2}\right.$; first $\mathrm{CH}_{2} \mathrm{Cl}_{2}$ then $\mathrm{CH}_{2} \mathrm{Cl}_{2}$ /acetone, 3:1) gave 2a as an orange solid (104 mg, 27\%). Addition of $\mathrm{Et}_{2} \mathrm{O}$ to a suspension of 2a in $\mathrm{CH}_{2} \mathrm{Cl}_{2}$ afforded analytically pure material. Anal. Calcd for $\mathrm{C}_{34} \mathrm{H}_{56} \mathrm{I}_{6} \mathrm{~N}_{8} \mathrm{Rh}_{2}$ (1544.10): C, 26.45; H, 3.66; N, 7.26. Found: C, 26.36; H, 3.66; N, 7.34.

Synthesis of $\mathbf{2 b}$. According to method A, starting from $\mathbf{1 b}$ (334 $\mathrm{mg}, 0.5 \mathrm{mmol}),[\mathrm{RhCl}(\mathrm{cod})]_{2}(123 \mathrm{mg}, 0.25 \mathrm{mmol}), \mathrm{KI}(332 \mathrm{mg}$, $2.0 \mathrm{mmol}$ ), and $\mathrm{NaOAc}(328 \mathrm{mg}, 4.0 \mathrm{mmol})$. Gradient column chromatography $\left(\mathrm{SiO}_{2}\right.$; first $\mathrm{CH}_{2} \mathrm{Cl}_{2}$ then $\mathrm{CH}_{2} \mathrm{Cl}_{2}$ /acetone, 5:1) gave $\mathbf{2 b}$ as an orange solid (140 mg, 31\%), which was then crystallized from $\mathrm{CH}_{2} \mathrm{Cl}_{2}$ /hexane. ${ }^{1} \mathrm{H}$ NMR $\left(\mathrm{CD}_{2} \mathrm{Cl}_{2}, 400 \mathrm{MHz}\right): \delta 7.63-7.23$ $\left(\mathrm{m}, 24 \mathrm{H}, \mathrm{H}_{\text {aryl }}, \mathrm{H}_{\mathrm{imi}}\right), 6.47\left(\mathrm{~d}, 2 \mathrm{H},{ }^{2} J_{\mathrm{HH}}=12.6 \mathrm{~Hz}\right.$, lowfield AX part of $\left.\mathrm{NCH}_{2} \mathrm{~N}\right), 5.86\left(\mathrm{~d}, 2 \mathrm{H},{ }^{2} \mathrm{~J}_{\mathrm{HH}}=12.6 \mathrm{~Hz}\right.$, high-field AX part of $\left.\mathrm{NCH}_{2} \mathrm{~N}\right), 3.98-3.91\left(\mathrm{~m}, 8 \mathrm{H}, \mathrm{CH}_{2} \mathrm{CH}_{2} \mathrm{CH}_{2} \mathrm{CH}_{3}\right), 1.84-1.75(\mathrm{~m}$, $\left.8 \mathrm{H}, \mathrm{CH}_{2} \mathrm{CH}_{2} \mathrm{CH}_{2} \mathrm{CH}_{3}\right), 1.32-1.27\left(\mathrm{~m}, 8 \mathrm{H}, \mathrm{CH}_{2} \mathrm{CH}_{2} \mathrm{CH}_{2} \mathrm{CH}_{3}\right)$, 0.89-0.84 (m, $\left.12 \mathrm{H}, \mathrm{CH}_{2} \mathrm{CH}_{2} \mathrm{CH}_{2} \mathrm{CH}_{3}\right) .{ }^{13} \mathrm{C}\left\{{ }^{1} \mathrm{H}\right\}$ NMR $\left(\mathrm{CD}_{2} \mathrm{Cl}_{2}\right.$, $100 \mathrm{MHz}): \delta 142.1,141.8\left(\mathrm{C}_{\mathrm{imi}-2}\right), 139.4\left(\mathrm{~d},{ }^{1} J_{\mathrm{CRh}}=42.0 \mathrm{~Hz}, \mathrm{C}_{\text {imi- }}\right.$ 5), $137.2\left(\mathrm{~d},{ }^{1} J_{\mathrm{CRh}}=42.0 \mathrm{~Hz}, \mathrm{C}_{\text {imi-5 }}\right), 132.1,131.9\left(\mathrm{C}_{\text {aryl }}\right)$, 130.0-129.5 (m, $\left.\mathrm{C}_{\text {imi- }-4}, \mathrm{C}_{\text {aryl }}\right), 61.1\left(\mathrm{NCH}_{2} \mathrm{~N}\right), 48.0\left(\mathrm{CH}_{2} \mathrm{CH}_{2} \mathrm{CH}_{2-}\right.$ $\left.\mathrm{CH}_{3}\right)$, 32.0, $31.9\left(\mathrm{CH}_{2} \mathrm{CH}_{2} \mathrm{CH}_{2} \mathrm{CH}_{3}\right), 19.4$, $19.3\left(\mathrm{CH}_{2} \mathrm{CH}_{2} \mathrm{CH}_{2} \mathrm{CH}_{3}\right)$, $12.9\left(\mathrm{CH}_{2} \mathrm{CH}_{2} \mathrm{CH}_{2} \mathrm{CH}_{3}\right)$. The signals of the two minor species are overlapping with the major product in the ${ }^{1} \mathrm{H}$ NMR spectrum except for the AX-type signal of the $\mathrm{NCH}_{2} \mathrm{~N}$ group; minor species $\mathrm{A}: \delta$ $6.31\left(\mathrm{~d},{ }^{2} J_{\mathrm{HH}}=12.6 \mathrm{~Hz}\right), 5.90\left(\mathrm{~d},{ }^{2} J_{\mathrm{HH}}=12.6 \mathrm{~Hz}\right)$; minor species B: $\delta 6.59\left(\mathrm{~d},{ }^{2} J_{\mathrm{HH}}=12.6 \mathrm{~Hz}\right), 5.69\left(\mathrm{~d},{ }^{2} J_{\mathrm{HH}}=12.6 \mathrm{~Hz}\right)$. Anal. Calcd for $\mathrm{C}_{54} \mathrm{H}_{64} \mathrm{I}_{6} \mathrm{~N}_{8} \mathrm{Rh}_{2}$ (1792.38): C, 36.19; H, 3.60; N, 6.25. Found: C, 36.09; H, 3.62; N, 5.91.

Synthesis of 2c. According to method A, starting from 1c (260 $\mathrm{mg}, 0.5 \mathrm{mmol}),[\mathrm{RhCl}(\mathrm{cod})]_{2}(123 \mathrm{mg}, 0.25 \mathrm{mmol}), \mathrm{KI}(332 \mathrm{mg}$, $2.0 \mathrm{mmol}$ ), and $\mathrm{NaOAc}(328 \mathrm{mg}, 4.0 \mathrm{mmol})$. Gradient column chromatography $\left(\mathrm{SiO}_{2}\right.$; first $\mathrm{CH}_{2} \mathrm{Cl}_{2}$ then $\mathrm{CH}_{2} \mathrm{Cl}_{2}$ /acetone, 5:1) gave $2 \mathrm{c}$ as an orange solid (50 mg, 13\%). Analytically pure material was obtained by slow diffusion of $\mathrm{Et}_{2} \mathrm{O}$ into a solution of $\mathbf{2 c}$ in $\mathrm{CH}_{2} \mathrm{Cl}_{2} / \mathrm{CH}_{3} \mathrm{CN}$ (8:1). Anal. Calcd for $\mathrm{C}_{30} \mathrm{H}_{48} \mathrm{I}_{6} \mathrm{~N}_{8} \mathrm{O}_{0.5} \mathrm{Rh}_{2}$ (1487.99) $\times 0.5 \mathrm{Et}_{2} \mathrm{O}: \mathrm{C}, 25.20 ; \mathrm{H}, 3.50 ; \mathrm{N}, 7.35$. Found: C, 25.20; H, 3.78; N, 7.58 .

Synthesis of 2d. According to method A, starting from 1d (320 $\mathrm{mg}, 0.5 \mathrm{mmol}),[\mathrm{RhCl}(\mathrm{cod})]_{2}(123 \mathrm{mg}, 0.25 \mathrm{mmol}), \mathrm{KI}(332 \mathrm{mg}$, $2.0 \mathrm{mmol}$ ), and $\mathrm{NaOAc}(328 \mathrm{mg}, 4.0 \mathrm{mmol})$. Gradient column chromatography $\left(\mathrm{SiO}_{2}\right.$; first $\mathrm{CH}_{2} \mathrm{Cl}_{2}$ then $\mathrm{CH}_{2} \mathrm{Cl}_{2}$ /acetone, 5:1) gave 2d as an orange solid (100 mg, 23\%), which was crystallized from $\mathrm{CH}_{2} \mathrm{Cl}_{2}$ /hexane. Anal. Calcd for $\mathrm{C}_{50} \mathrm{H}_{56} \mathrm{I}_{6} \mathrm{~N}_{8} \mathrm{Rh}_{2}$ (1736.27): C, 34.59; H, 3.25; N, 6.45. Found: C, 34.21; H, 3.31; N, 6.77.

Synthesis of 2e. According to method B, starting from 1e (201 mg, $0.3 \mathrm{mmol}),\left[\mathrm{RhCl}_{3}\left(\mathrm{H}_{2} \mathrm{O}\right)_{\mathrm{x}}\right](79 \mathrm{mg}, 0.3 \mathrm{mmol})$, and $\mathrm{NaOAc}$ (197 mg, $2.4 \mathrm{mmol}$ ) afforded $2 \mathrm{e}$ as an orange solid (110 mg, 41\%). Analytically pure material was obtained by slow diffusion of $\mathrm{Et}_{2} \mathrm{O}$ into a solution of $\mathbf{2} \mathbf{e}$ in $\mathrm{CH}_{2} \mathrm{Cl}_{2}$ /acetone (1:1). Anal. Calcd for $\mathrm{C}_{54} \mathrm{H}_{64} \mathrm{I}_{6} \mathrm{~N}_{8} \mathrm{Rh}_{2}$ (1792.38): C, 36.19; H, 3.60; N, 6.25. Found: C, 36.23; H, 3.71; N, 6.16.

Synthesis of 3a. Crystallization of $\mathbf{2 a}$ from $\mathrm{CH}_{3} \mathrm{CN} / \mathrm{Et}_{2} \mathrm{O}$ afforded the monomeric bis-acetonitrile complex 3a. ${ }^{1} \mathrm{H}$ NMR $\left(\mathrm{CD}_{3} \mathrm{CN}, 400 \mathrm{MHz}\right): \delta 6.90\left(\mathrm{~s}, 2 \mathrm{H}, \mathrm{H}_{\mathrm{imi}}\right), 6.19\left(\mathrm{~s}, 2 \mathrm{H}, \mathrm{NCH}_{2} \mathrm{~N}\right)$, $4.01\left(\mathrm{t}, 4 \mathrm{H},{ }^{3} \mathrm{~J}_{\mathrm{HH}}=7.2 \mathrm{~Hz}, \mathrm{CH}_{2} \mathrm{CH}_{2} \mathrm{CH}_{2} \mathrm{CH}_{3}\right), 2.67\left(\mathrm{~s}, 6 \mathrm{H}, \mathrm{CH}_{3}\right)$, 1.74 (quintet, $4 \mathrm{H},{ }^{3} J_{\mathrm{HH}}=7.2 \mathrm{~Hz}, \mathrm{CH}_{2} \mathrm{CH}_{2} \mathrm{CH}_{2} \mathrm{CH}_{3}$ ), 1.34 (sextet, $4 \mathrm{H},{ }^{3} J_{\mathrm{HH}}=7.2 \mathrm{~Hz}, \mathrm{CH}_{2} \mathrm{CH}_{2} \mathrm{CH}_{2} \mathrm{CH}_{3}$ ), $0.94\left(\mathrm{t}, 6 \mathrm{H},{ }^{3} J_{\mathrm{HH}}\right.$ $\left.=7.2 \mathrm{~Hz}, \mathrm{CH}_{2} \mathrm{CH}_{2} \mathrm{CH}_{2} \mathrm{CH}_{3}\right) \cdot{ }^{13} \mathrm{C}\left\{{ }^{1} \mathrm{H}\right\}$ NMR $\left(\mathrm{CD}_{3} \mathrm{CN}, 100\right.$ $\mathrm{MHz}): \delta 143.0\left(\mathrm{C}_{\mathrm{imi}}\right), 130.0\left(\mathrm{C}-\mathrm{Rh},{ }^{1} J_{\mathrm{CRh}}=38.0 \mathrm{~Hz}\right), 127.2$ $\left(\mathrm{C}_{\mathrm{imi}}\right), 62.4\left(\mathrm{NCH}_{2} \mathrm{~N}\right), 48.9\left(\mathrm{CH}_{2} \mathrm{CH}_{2} \mathrm{CH}_{2} \mathrm{CH}_{3}\right), 33.3\left(\mathrm{CH}_{2} \mathrm{CH}_{2} \mathrm{CH}_{2-}\right.$ $\left.\mathrm{CH}_{3}\right), 20.8\left(\mathrm{CH}_{2} \mathrm{CH}_{2} \mathrm{CH}_{2} \mathrm{CH}_{3}\right), 14.4\left(\mathrm{CH}_{2} \mathrm{CH}_{2} \mathrm{CH}_{2} \mathrm{CH}_{3}\right), 11.2$ $\left(\mathrm{CH}_{3}\right)$. Anal. Calcd for $\mathrm{C}_{21} \mathrm{H}_{34} \mathrm{I}_{3} \mathrm{~N}_{6} \mathrm{Rh}(845.15) \times \mathrm{CH}_{3} \mathrm{CN}: \mathrm{C}$, 30.86; H, 4.17; N, 10.95. Found: C, 30.96; H, 4.13; N, 10.89.

Synthesis of $\mathbf{3 b}$. Slow diffusion of $\mathrm{Et}_{2} \mathrm{O}$ into a solution of 2b in $\mathrm{CH}_{2} \mathrm{Cl}_{2} / \mathrm{CH}_{3} \mathrm{CN}$ (1:1) induced crystallization of complex 3b. ${ }^{1} \mathrm{H}$ NMR $\left(\mathrm{CD}_{3} \mathrm{CN}, 400 \mathrm{MHz}\right): \delta 7.59\left(\mathrm{t}, 2 \mathrm{H},{ }^{3} \mathrm{~J}_{\mathrm{HH}}=7.6\right.$
$\left.\mathrm{Hz}, \mathrm{H}_{\text {aryl }}\right), 7.48\left(\mathrm{t}, 4 \mathrm{H},{ }^{3} J_{\mathrm{HH}}=7.6 \mathrm{~Hz}, \mathrm{H}_{\text {aryl }}\right), 7.36\left(\mathrm{~d}, 4 \mathrm{H},{ }^{3} J_{\mathrm{HH}}\right.$ $\left.=7.6 \mathrm{~Hz}, \mathrm{H}_{\text {aryl }}\right), 7.20\left(\mathrm{~s}, 2 \mathrm{H}, \mathrm{H}_{\text {imi }}\right), 6.00\left(\mathrm{~s}, 2 \mathrm{H}, \mathrm{NCH}_{2} \mathrm{~N}\right), 3.91$ (t, $4 \mathrm{H},{ }^{3} J_{\mathrm{HH}}=7.2 \mathrm{~Hz}, \mathrm{CH}_{2} \mathrm{CH}_{2} \mathrm{CH}_{2} \mathrm{CH}_{3}$ ), 1.68 (quintet, $4 \mathrm{H}$, ${ }^{3} J_{\mathrm{HH}}=7.2 \mathrm{~Hz}, \mathrm{CH}_{2} \mathrm{CH}_{2} \mathrm{CH}_{2} \mathrm{CH}_{3}$ ), 1.20 (sextet, $4 \mathrm{H},{ }^{3} J_{\mathrm{HH}}=7.2$ $\left.\mathrm{Hz}, \quad \mathrm{CH}_{2} \mathrm{CH}_{2} \mathrm{CH}_{2} \mathrm{CH}_{3}\right), 0.78\left(\mathrm{t}, 6 \mathrm{H},{ }^{3} J_{\mathrm{HH}}=7.2 \mathrm{~Hz}\right.$, $\left.\mathrm{CH}_{2} \mathrm{CH}_{2} \mathrm{CH}_{2} \mathrm{CH}_{3}\right) .{ }^{13} \mathrm{C}\left\{{ }^{1} \mathrm{H}\right\} \mathrm{NMR}\left(\mathrm{CD}_{3} \mathrm{CN}, 100 \mathrm{MHz}\right): \delta 143.8$ $\left(\mathrm{C}_{\mathrm{imi}}\right), 133.0\left(\mathrm{C}_{\mathrm{aryl}}\right), 132.2\left(\mathrm{C}-\mathrm{Rh},{ }^{1} J_{\mathrm{CRh}}=38.0 \mathrm{~Hz}\right), 131.7$ $\left(\mathrm{C}_{\text {aryl }}\right), 130.5\left(\mathrm{C}_{\text {aryl }}\right), 128.0\left(\mathrm{C}_{\mathrm{imi}}\right), 122.9\left(\mathrm{C}_{\text {aryl }}\right), 62.8\left(\mathrm{NCH}_{2} \mathrm{~N}\right)$, $48.8 \quad\left(\mathrm{CH}_{2} \mathrm{CH}_{2} \mathrm{CH}_{2} \mathrm{CH}_{3}\right), \quad 32.7 \quad\left(\mathrm{CH}_{2} \mathrm{CH}_{2} \mathrm{CH}_{2} \mathrm{CH}_{3}\right), \quad 20.0$ $\left(\mathrm{CH}_{2} \mathrm{CH}_{2} \mathrm{CH}_{2} \mathrm{CH}_{3}\right), 13.7\left(\mathrm{CH}_{2} \mathrm{CH}_{2} \mathrm{CH}_{2} \mathrm{CH}_{3}\right)$.

Synthesis of 3c. Slow diffusion of $\mathrm{Et}_{2} \mathrm{O}$ into a solution of $\mathbf{2 c}$ in $\mathrm{CH}_{3} \mathrm{CN}$ yielded crystals of complex 3c. ${ }^{1} \mathrm{H}$ NMR $\left(\mathrm{CD}_{3} \mathrm{CN}\right.$, $400 \mathrm{MHz}): \delta 6.97\left(\mathrm{~s}, 2 \mathrm{H}, \mathrm{H}_{\mathrm{imi}}\right), 6.25\left(\mathrm{~s}, 2 \mathrm{H}, \mathrm{NCH}_{2} \mathrm{~N}\right), 4.52$ (septet, $\left.2 \mathrm{H},{ }^{3} J_{\mathrm{HH}}=6.6 \mathrm{~Hz}, \mathrm{CHMe}_{2}\right), 2.70\left(\mathrm{~s}, 6 \mathrm{H}, \mathrm{CH}_{3}\right), 1.46$ $\left(\mathrm{d}, 12 \mathrm{H},{ }^{3} J_{\mathrm{HH}}=6.6 \mathrm{~Hz}, \mathrm{CH}\left(\mathrm{CH}_{3}\right)_{2}\right) .{ }^{13} \mathrm{C}\left\{{ }^{1} \mathrm{H}\right\} \mathrm{NMR}\left(\mathrm{CD}_{3} \mathrm{CN}\right.$, $100 \mathrm{MHz}): \delta 141.7\left(\mathrm{C}_{\mathrm{imi}}\right), 129.8\left(\mathrm{C}-\mathrm{Rh},{ }^{1} J_{\mathrm{CRh}}=38.0 \mathrm{~Hz}\right)$, $122.4\left(\mathrm{C}_{\mathrm{imi}}\right), 61.5\left(\mathrm{NCH}_{2} \mathrm{~N}\right), 50.8\left(\mathrm{CHMe}_{2}\right), 22.6\left(\mathrm{CH}\left(\mathrm{CH}_{3}\right)_{2}\right)$, $10.8\left(\mathrm{CH}_{3}\right)$.

Synthesis of 3d. Saturation of a solution of $\mathbf{2 d}$ in $\mathrm{CH}_{2} \mathrm{Cl}_{2}$ / $\mathrm{CH}_{3} \mathrm{CN}(1: 1)$ with $\mathrm{Et}_{2} \mathrm{O}$ gave complex 3d. ${ }^{1} \mathrm{H}$ NMR $\left(\mathrm{CD}_{3} \mathrm{CN}\right.$, $400 \mathrm{MHz}): \delta 7.59\left(\mathrm{t}, 2 \mathrm{H},{ }^{3} J_{\mathrm{HH}}=7.6 \mathrm{~Hz}, \mathrm{H}_{\text {aryl }}\right), 7.48(\mathrm{t}, 4 \mathrm{H}$, $\left.{ }^{3} J_{\mathrm{HH}}=7.6 \mathrm{~Hz}, \mathrm{H}_{\text {aryl }}\right), 7.36\left(\mathrm{~d}, 4 \mathrm{H},{ }^{3} J_{\mathrm{HH}}=7.6 \mathrm{~Hz}, \mathrm{H}_{\text {aryl }}\right), 7.28$ (s, $\left.2 \mathrm{H}, \mathrm{H}_{\mathrm{imi}}\right), 5.99\left(\mathrm{~s}, 2 \mathrm{H}, \mathrm{NCH}_{2} \mathrm{~N}\right), 4.25$ (septet, $2 \mathrm{H},{ }^{3} \mathrm{~J}_{\mathrm{HH}}=$ $\left.6.6 \mathrm{~Hz}, \mathrm{CHMe}_{2}\right), 1.44\left(\mathrm{~d}, 12 \mathrm{H},{ }^{3} \mathrm{~J}_{\mathrm{HH}}=6.6 \mathrm{~Hz}, \mathrm{CH}\left(\mathrm{CH}_{3}\right)_{2}\right)$. ${ }^{13} \mathrm{C}\left\{{ }^{1} \mathrm{H}\right\} \mathrm{NMR}\left(\mathrm{CD}_{3} \mathrm{CN}, 100 \mathrm{MHz}\right): \delta 142.9\left(\mathrm{C}_{\mathrm{imi}}\right), 133.0\left(\mathrm{C}_{\text {aryl }}\right)$, $132.6\left(\mathrm{C}-\mathrm{Rh},{ }^{1} J_{\mathrm{CRh}}=38.0 \mathrm{~Hz}\right), 131.6\left(\mathrm{C}_{\text {aryl }}\right), 130.5\left(\mathrm{C}_{\text {aryl }}\right)$, $124.2\left(\mathrm{C}_{\text {imi }}\right), 123.0\left(\mathrm{C}_{\text {aryl }}\right), 62.4\left(\mathrm{NCH}_{2} \mathrm{~N}\right), 51.8\left(\mathrm{CHMe}_{2}\right), 23.0$ $\left(\mathrm{CH}\left(\mathrm{CH}_{3}\right)_{2}\right.$.

Synthesis of 3e. Dissolution of $\mathbf{2} \mathbf{e}$ in $\mathrm{CH}_{3} \mathrm{CN}$ and subsequent precipitation with $\mathrm{Et}_{2} \mathrm{O}$ gave the monometallic complex $3 \mathbf{e} .{ }^{1} \mathrm{H}$ NMR $\left(\mathrm{CD}_{3} \mathrm{CN}, 500 \mathrm{MHz}\right): \delta 7.13\left(\mathrm{~s}, 4 \mathrm{H}, \mathrm{H}_{\mathrm{Mes}}\right), 6.88(\mathrm{~s}, 2 \mathrm{H}$, $\left.\mathrm{H}_{\mathrm{imi}}\right), 6.35\left(\mathrm{~s}, 2 \mathrm{H}, \mathrm{NCH}_{2} \mathrm{~N}\right), 2.46\left(\mathrm{~s}, 6 \mathrm{H}, \mathrm{CH}_{3}\right), 2.36(\mathrm{~s}, 6 \mathrm{H}$, $\left.\mathrm{CH}_{3}\right), 2.03$ (s, 12H, CH 3$) .{ }^{13} \mathrm{C}\left\{{ }^{1} \mathrm{H}\right\}$ NMR $\left(\mathrm{CD}_{3} \mathrm{CN}, 125 \mathrm{MHz}\right)$ : $\delta 143.4\left(\mathrm{C}_{\mathrm{imi}}\right), 141.5\left(\mathrm{C}_{\mathrm{Mes}}\right), 136.0\left(\mathrm{C}_{\mathrm{Mes}}\right), 132.2\left(\mathrm{C}_{\text {Mes }}\right), 130.6$ $\left(\mathrm{C}-\mathrm{Rh},{ }^{1} J_{\mathrm{CRh}}=37.9 \mathrm{~Hz}\right), 130.3\left(\mathrm{C}_{\mathrm{Mes}}\right), 126.6\left(\mathrm{C}_{\mathrm{imi}}\right), 62.3$ $\left(\mathrm{NCH}_{2} \mathrm{~N}\right), 21.1\left(\mathrm{Mes}-\mathrm{CH}_{3}\right), 17.6\left(\mathrm{Mes}-\mathrm{CH}_{3}\right), 10.5\left(\mathrm{Imi}-\mathrm{CH}_{3}\right)$.

Synthesis of 3f. A mixture of $[\mathrm{RhCl}(\operatorname{cod})]_{2}(100 \mathrm{mg}, 0.20$ mmol), methylene-1,1'-di(3,3'-n-butyl)imidazolium diiodide (212 $\mathrm{mg}, 0.41 \mathrm{mmol}), \mathrm{KI}$ (220 mg, $1.3 \mathrm{mmol})$, and $\mathrm{NEt}_{3}$ (0.25 g, 2.5 mmol) was stirred in $\mathrm{CH}_{3} \mathrm{CN}(12 \mathrm{~mL})$ at $50{ }^{\circ} \mathrm{C}$. The color of the mixture gradually changed from yellow to dark red. After $1 \mathrm{~h}$, the solids were filtered off and the filtrate was evaporated under reduced pressure. The residue was purified by gradient column chromatography $\left(\mathrm{SiO}_{2}, \mathrm{CH}_{2} \mathrm{Cl}_{2}\right.$ to $\mathrm{CH}_{2} \mathrm{Cl}_{2}$ /acetone (3: 1 ) as eluents). The red fraction was collected and afforded after evaporation crude 3f (208 mg, 61\%). Recrystallization from $\mathrm{CH}_{3} \mathrm{CN} / \mathrm{Et}_{2} \mathrm{O} /$ hexanes gave an analytically pure sample of $\mathbf{3 f}$. ${ }^{1} \mathrm{H}$ NMR $\left(\mathrm{CD}_{3} \mathrm{CN}, 400 \mathrm{MHz}\right): \delta 7.43\left(\mathrm{~d}, 2 \mathrm{H},{ }^{3} \mathrm{~J}_{\mathrm{HH}}=1.9 \mathrm{~Hz}\right.$, $\left.\mathrm{H}_{\mathrm{imi}}\right), 7.37\left(\mathrm{~d}, 2 \mathrm{H},{ }^{3} J_{\mathrm{HH}}=1.9 \mathrm{~Hz}, \mathrm{H}_{\mathrm{imi}}\right), 6.38\left(\mathrm{~s}, 2 \mathrm{H}, \mathrm{NCH}_{2} \mathrm{~N}\right)$, $4.40\left(\mathrm{~m}, 4 \mathrm{H}, \mathrm{CH}_{2} \mathrm{CH}_{2} \mathrm{CH}_{2} \mathrm{CH}_{3}\right), 1.98\left(\mathrm{~s}, 6 \mathrm{H}, \mathrm{NCCH}_{3}\right), 1.83$ (m, $4 \mathrm{H}, \mathrm{CH}_{2} \mathrm{CH}_{2} \mathrm{CH}_{2} \mathrm{CH}_{3}$ ), 1.45 (sextet, $4 \mathrm{H},{ }^{3} \mathrm{~J}_{\mathrm{HH}}=7.4 \mathrm{~Hz}$, $\left.\mathrm{CH}_{2} \mathrm{CH}_{2} \mathrm{CH}_{2} \mathrm{CH}_{3}\right), 1.00\left(\mathrm{t}, 6 \mathrm{H},{ }^{3} J_{\mathrm{HH}}=7.4 \mathrm{~Hz}, \mathrm{CH}_{2} \mathrm{CH}_{2-}\right.$ $\left.\mathrm{CH}_{2} \mathrm{CH}_{3}\right) .{ }^{13} \mathrm{C}\left\{{ }^{1} \mathrm{H}\right\}$ NMR $\left(\mathrm{CD}_{3} \mathrm{CN}, 100 \mathrm{MHz}\right): \delta 149.0(\mathrm{C}-\mathrm{Rh}$, $\left.{ }^{1} J_{\mathrm{CRh}}=42.7 \mathrm{~Hz}\right), 124.2\left(\mathrm{C}_{\mathrm{imi}}\right), 123.8\left(\mathrm{C}_{\mathrm{imi}}\right), 65.7\left(\mathrm{NCH}_{2} \mathrm{~N}\right)$, $53.3 \quad\left(\mathrm{CH}_{2} \mathrm{CH}_{2} \mathrm{CH}_{2} \mathrm{CH}_{3}\right), \quad 33.8 \quad\left(\mathrm{CH}_{2} \mathrm{CH}_{2} \mathrm{CH}_{2} \mathrm{CH}_{3}\right), \quad 20.6$ $\left(\mathrm{CH}_{2} \mathrm{CH}_{2} \mathrm{CH}_{2} \mathrm{CH}_{3}\right), 14.1\left(\mathrm{CH}_{2} \mathrm{CH}_{2} \mathrm{CH}_{2} \mathrm{CH}_{3}\right)$. Anal. Calcd for $\mathrm{C}_{19} \mathrm{H}_{30} \mathrm{I}_{3} \mathrm{~N}_{6} \mathrm{Rh}$ (825.87): C, 27.62; H, 3.66; N, 10.17. Found: C, 27.69; H, 3.76; N, 9.64.

Synthesis of $\mathbf{3 g}$. Following a procedure as described for $\mathbf{3 f}$, the title product was obtained from a mixture of $[\mathrm{RhCl}(\operatorname{cod})]_{2}$ (243 mg, $0.50 \mathrm{mmol}), N, N$-methylenedi $\left(N^{\prime}\right.$-mesityl)imidazolium diiodide (640 mg, $1.0 \mathrm{mmol}$ ), $\mathrm{NaI}$ (500 mg, $3.3 \mathrm{mmol}$ ), and $\mathrm{NEt}_{3}(0.45 \mathrm{~g}, 4.5 \mathrm{mmol})$ in $\mathrm{CH}_{3} \mathrm{CN}(20 \mathrm{~mL})$ as a red powder (yield $647 \mathrm{mg}, 70 \%$ ). Recrystallization from $\mathrm{CH}_{3} \mathrm{CN} / \mathrm{Et}_{2} \mathrm{O}$ gave 
an analytically pure sample of $\mathbf{3 g} .{ }^{1} \mathrm{H}$ NMR $\left(\mathrm{CD}_{3} \mathrm{CN}, 500 \mathrm{MHz}\right)$ : $\delta 7.58\left(\mathrm{~d}, 2 \mathrm{H},{ }^{3} \mathrm{~J}_{\mathrm{HH}}=2.2 \mathrm{~Hz}, \mathrm{H}_{\mathrm{imi}}\right), 7.13\left(\mathrm{~d}, 2 \mathrm{H},{ }^{3} J_{\mathrm{HH}}=2.2\right.$ $\mathrm{Hz}, \mathrm{H}_{\mathrm{imi}}$ ), 6.99 (s, 4H, Hes $), 6.45$ (s, 2H, $\left.\mathrm{NCH}_{2} \mathrm{~N}\right), 2.30$ (s, $\left.6 \mathrm{H}, \mathrm{CH}_{3}\right), 2.21\left(\mathrm{~s}, 12 \mathrm{H}, \mathrm{CH}_{3}\right) .{ }^{13} \mathrm{C}\left\{{ }^{1} \mathrm{H}\right\}$ NMR $\left(\mathrm{CD}_{3} \mathrm{CN}, 125\right.$ $\mathrm{MHz}): \delta 150.87\left(\mathrm{C}-\mathrm{Rh},{ }^{1} J_{\mathrm{CRh}}=43.2 \mathrm{~Hz}\right), 140.69\left(\mathrm{C}_{\mathrm{Mes}}\right)$, $138.23\left(\mathrm{C}_{\mathrm{Mes}}\right), 136.51$ ( $\left.\mathrm{C}_{\mathrm{Mes}}\right), 129.64\left(\mathrm{C}_{\mathrm{Mes}}\right), 127.83\left(\mathrm{C}_{\mathrm{imi}}\right)$, $123.78\left(\mathrm{C}_{\text {imi }}\right), 65.61\left(\mathrm{NCH}_{2} \mathrm{~N}\right), 21.03\left(\mathrm{CH}_{3}\right.$ ortho $), 20.91\left(\mathrm{CH}_{3}\right.$ para). Anal. Calcd for $\mathrm{C}_{29} \mathrm{H}_{34} \mathrm{I}_{3} \mathrm{~N}_{6} \mathrm{Rh}$ (950.24): C, 36.66; H, 3.61; N, 8.84. Found: C, 36.86; H, 3.67; N, 8.82.

Synthesis of $\left[\mathrm{RhCl}_{2}\right.$ (dicarbene $)\left(\mathrm{MeCN}_{2}\right] \mathrm{BF}_{4}(4)$. A suspension of $\mathbf{1 b}(460 \mathrm{mg}, 0.69 \mathrm{mmol})$ and $\mathrm{AgBF}_{4}(296 \mathrm{mg}, 1.5 \mathrm{mmol})$ in $\mathrm{CH}_{2} \mathrm{Cl}_{2}(100 \mathrm{~mL})$ was stirred at room temperature and in the dark for $24 \mathrm{~h}$. The reaction mixture was filtered and the filtrate concentrated under reduced pressure to ca. $5 \mathrm{~mL}$. Upon addition of $\mathrm{Et}_{2} \mathrm{O}$, an off-white precipitate formed, which analyzed as $N, N$ methylenedi $\left(N^{\prime}-n\right.$-butyl-2-phenyl)imidazolium $\left(\mathrm{BF}_{4}\right)_{2}\left(\mathbf{1 b}^{\prime}\right)$. Yield: $293 \mathrm{mg}(72 \%) .{ }^{1} \mathrm{H}$ NMR (DMSO- $\left.d_{6}, 360 \mathrm{MHz}\right): \delta 8.03(\mathrm{~s}, 2 \mathrm{H}$, $\left.\mathrm{H}_{\mathrm{imi}}\right), 7.89$ (s, 2H, $\left.\mathrm{H}_{\mathrm{imi}}\right), 7.70\left(\mathrm{~m}, 2 \mathrm{H}, \mathrm{H}_{\text {aryl }}\right), 7.60\left(\mathrm{~m}, 4 \mathrm{H}, \mathrm{H}_{\text {aryl }}\right)$, $7.55\left(\mathrm{~m}, 4 \mathrm{H}, \mathrm{H}_{\mathrm{aryl}}\right), 6.27\left(\mathrm{~s}, 2 \mathrm{H}, \mathrm{NCH}_{2} \mathrm{~N}\right), 3.90\left(\mathrm{~m}, 4 \mathrm{H},{ }^{3} \mathrm{~J}_{\mathrm{HH}}=\right.$ $\left.7.1 \mathrm{~Hz}, \mathrm{NCH}_{2} \mathrm{CH}_{2} \mathrm{CH}_{2} \mathrm{CH}_{3}\right), 1.56\left(\mathrm{~m}, 4 \mathrm{H}, \mathrm{NCH}_{2} \mathrm{CH}_{2} \mathrm{CH}_{2} \mathrm{CH}_{3}\right)$, $1.07\left(\mathrm{~m}, 4 \mathrm{H}, \mathrm{NCH}_{2} \mathrm{CH}_{2} \mathrm{CH}_{2} \mathrm{CH}_{3}\right), 0.71\left(\mathrm{t}, 6 \mathrm{H},{ }^{3} J_{\mathrm{HH}}=7.2 \mathrm{~Hz}\right.$, $\mathrm{NCH}_{2} \mathrm{CH}_{2} \mathrm{CH}_{2} \mathrm{CH}_{3}$ ).

This product $\mathbf{1 b}^{\prime}(293 \mathrm{mg}, 0.50 \mathrm{mmol}),\left[\mathrm{RhCl}_{3}\left(\mathrm{H}_{2} \mathrm{O}\right)_{x}\right](131$ $\mathrm{mg}, 0.50 \mathrm{mmol})$, and $\mathrm{NaOAc}(327 \mathrm{mg}, 4.0 \mathrm{mmol})$ were suspended in $\mathrm{MeCN}$ (40 mL) and stirred at reflux temperature for $24 \mathrm{~h}$. After cooling, all volatiles were removed under reduced pressure, and the residue was purified by gradient column chromatography $\left(\mathrm{SiO}_{2}\right.$; first $\mathrm{CH}_{2} \mathrm{Cl}_{2}$ then $\mathrm{CH}_{2} \mathrm{Cl}_{2}$ /acetone, 10: 1). The yellow fraction was collected and evaporated to dryness to give 4 as a yellow, crystalline solid (yield: $177 \mathrm{mg}, 55 \%$ ). Analytically pure crystals of the title product were obtained by slow diffusion of hexane into a solution of 4 in $\mathrm{CH}_{2} \mathrm{Cl}_{2} \cdot{ }^{1} \mathrm{H}$ NMR $\left(\mathrm{CD}_{3} \mathrm{CN}, 500 \mathrm{MHz}\right): \delta 7.58\left(\mathrm{~d}, 2 \mathrm{H},{ }^{3} \mathrm{~J}_{\mathrm{HH}}=7.9 \mathrm{~Hz}, \mathrm{H}_{\text {aryl }}\right)$, $7.46\left(\mathrm{t}, 4 \mathrm{H},{ }^{3} J_{\mathrm{HH}}=7.9 \mathrm{~Hz}, \mathrm{H}_{\text {aryl }}\right), 7.37\left(\mathrm{~d}, 4 \mathrm{H},{ }^{3} J_{\mathrm{HH}}=7.9 \mathrm{~Hz}\right.$, $\left.\mathrm{H}_{\text {aryl }}\right), 7.19$ (s, 2H, Himi $), 6.03\left(\mathrm{~s}, 2 \mathrm{H}, \mathrm{NCH}_{2} \mathrm{~N}\right), 3.93(\mathrm{t}, 4 \mathrm{H}$, ${ }^{3} J_{\mathrm{HH}}=7.5 \mathrm{~Hz}, \mathrm{CH}_{2} \mathrm{CH}_{2} \mathrm{CH}_{2} \mathrm{CH}_{3}$ ), 1.69 (quintet, $4 \mathrm{H},{ }^{3} J_{\mathrm{HH}}=$ $7.5 \mathrm{~Hz}, \mathrm{CH}_{2} \mathrm{CH}_{2} \mathrm{CH}_{2} \mathrm{CH}_{3}$ ), 1.20 (sextet, $4 \mathrm{H},{ }^{3} \mathrm{~J}_{\mathrm{HH}}=7.5 \mathrm{~Hz}$, $\left.\mathrm{CH}_{2} \mathrm{CH}_{2} \mathrm{CH}_{2} \mathrm{CH}_{3}\right), 0.79\left(\mathrm{t}, 6 \mathrm{H},{ }^{3} \mathrm{~J}_{\mathrm{HH}}=7.5 \mathrm{~Hz}, \mathrm{CH}_{2} \mathrm{CH}_{2}-\right.$ $\left.\mathrm{CH}_{2} \mathrm{CH}_{3}\right) \cdot{ }^{13} \mathrm{C}\left\{{ }^{1} \mathrm{H}\right\}$ NMR $\left(\mathrm{CD}_{3} \mathrm{CN}, 125 \mathrm{MHz}\right): \delta 143.6\left(\mathrm{C}_{\mathrm{imi}}\right)$, $134.3\left(\mathrm{C}-\mathrm{Rh},{ }^{1} J_{\mathrm{CRh}}=39.5 \mathrm{~Hz}\right), 132.9\left(\mathrm{C}_{\text {aryl }}\right), 131.5\left(\mathrm{C}_{\text {aryl }}\right)$, $130.3\left(\mathrm{C}_{\text {aryl }}\right), 124.6\left(\mathrm{C}_{\text {imi }}\right), 122.9\left(\mathrm{C}_{\text {aryl }}\right), 59.9\left(\mathrm{NCH}_{2} \mathrm{~N}\right), 48.7$ $\left(\mathrm{CH}_{2} \mathrm{CH}_{2} \mathrm{CH}_{2} \mathrm{CH}_{3}\right), 32.7\left(\mathrm{CH}_{2} \mathrm{CH}_{2} \mathrm{CH}_{2} \mathrm{CH}_{3}\right), 20.1\left(\mathrm{CH}_{2} \mathrm{CH}_{2} \mathrm{CH}_{2}-\right.$ $\left.\mathrm{CH}_{3}\right), 13.5\left(\mathrm{CH}_{2} \mathrm{CH}_{2} \mathrm{CH}_{2} \mathrm{CH}_{3}\right)$. Anal. Calcd for $\mathrm{C}_{27} \mathrm{H}_{32} \mathrm{BCl}_{2}-$ $\mathrm{F}_{4} \mathrm{~N}_{4} \mathrm{Rh}$ (673.19): C, 48.17; H 4.79; N 8.32. Found: C, 48.50; $\mathrm{H}, 5.20 ; \mathrm{N}, 8.57$.

[RhI $\mathbf{R}_{\mathbf{2}}$ (dicarbene) $\left(\mathbf{P P h}_{\mathbf{3}}\right)_{2} \mathbf{\text { I }}$ (5). To a solution of $\mathbf{2 b}$ (40 mg, $0.02 \mathrm{mmol})$ in $\mathrm{CH}_{2} \mathrm{Cl}_{2}(5 \mathrm{~mL})$ was added $\mathrm{PPh}_{3}(26 \mathrm{mg}, 0.1$ $\mathrm{mmol})$. The mixture was stirred at $\mathrm{rt}$ for $2 \mathrm{~h}$ and subsequently added dropwise to $\mathrm{Et}_{2} \mathrm{O}(100 \mathrm{~mL})$. The formed precipitate was separated by centrifugation and dried under vacuum $(40 \mathrm{mg}$, $70 \%)$. Analytically pure material was obtained by crystallization from $\mathrm{ClC}_{2} \mathrm{H}_{4} \mathrm{Cl} / \mathrm{Et}_{2} \mathrm{O}$. The three species show similar ${ }^{1} \mathrm{H} \mathrm{NMR}$ spectra except the $\mathrm{H}_{\mathrm{imi}}$ and bridged $\mathrm{CH}_{2}$. Major species: ${ }^{1} \mathrm{H}$ NMR $\left(\mathrm{CD}_{2} \mathrm{Cl}_{2}, 400 \mathrm{MHz}\right): \delta$ 7.67-7.26 (m, 40H, $\left.\mathrm{H}_{\text {aryl }}\right), 6.65$ $\left(\mathrm{s}, 2 \mathrm{H}, \mathrm{H}_{\mathrm{imi}}\right), 5.02\left(\mathrm{~s}, 2 \mathrm{H}, \mathrm{NCH}_{2} \mathrm{~N}\right), 3.20(\mathrm{~m}, 4 \mathrm{H}$, $\left.\mathrm{CH}_{2} \mathrm{CH}_{2} \mathrm{CH}_{2} \mathrm{CH}_{3}\right), 1.41$ (m, 4H, $\left.\mathrm{CH}_{2} \mathrm{CH}_{2} \mathrm{CH}_{2} \mathrm{CH}_{3}\right), 1.15$ (m, 4H, $\mathrm{CH}_{2} \mathrm{CH}_{2} \mathrm{CH}_{2} \mathrm{CH}_{3}$ ), $0.83\left(\mathrm{~m}, 6 \mathrm{H}, \mathrm{CH}_{2} \mathrm{CH}_{2} \mathrm{CH}_{2} \mathrm{CH}_{3}\right) .{ }^{31} \mathrm{P}\left\{{ }^{1} \mathrm{H}\right\}$ NMR $\left(\mathrm{CD}_{2} \mathrm{Cl}_{2}, 162 \mathrm{MHz}\right): \delta 12.3\left(\mathrm{~d},{ }^{1} J_{\mathrm{PRh}}=89.7 \mathrm{~Hz}\right)$. Minor species A: ${ }^{1} \mathrm{H}$ NMR $\left(\mathrm{CD}_{2} \mathrm{Cl}_{2}, 400 \mathrm{MHz}\right): \delta 6.57\left(\mathrm{~s}, 2 \mathrm{H}, \mathrm{H}_{\mathrm{imi}}\right)$, $5.06\left(\mathrm{~s}, 2 \mathrm{H}, \mathrm{NCH}_{2} \mathrm{~N}\right) .{ }^{31} \mathrm{P}\left\{{ }^{1} \mathrm{H}\right\} \mathrm{NMR}\left(\mathrm{CD}_{2} \mathrm{Cl}_{2}, 162 \mathrm{MHz}\right): \delta$ $15.2\left(\mathrm{~d},{ }^{1} J_{\mathrm{PRh}}=93.5 \mathrm{~Hz}\right)$. Minor species B: ${ }^{1} \mathrm{H} \mathrm{NMR}\left(\mathrm{CD}_{2} \mathrm{Cl}_{2}\right.$, $400 \mathrm{MHz}): \delta 6.39\left(\mathrm{~s}, 2 \mathrm{H}, \mathrm{H}_{\mathrm{imi}}\right), 5.06\left(\mathrm{~s}, 2 \mathrm{H}, \mathrm{NCH}_{2} \mathrm{~N}\right) .{ }^{31} \mathrm{P}\left\{{ }^{1} \mathrm{H}\right\}$ NMR $\left(\mathrm{CD}_{2} \mathrm{Cl}_{2}, 162 \mathrm{MHz}\right): \delta 15.2\left(\mathrm{~d},{ }^{1} J_{\mathrm{PRh}}=93.5 \mathrm{~Hz}\right)$. Anal.
Calcd for $\mathrm{C}_{63} \mathrm{H}_{62} \mathrm{I}_{3} \mathrm{~N}_{4} \mathrm{P}_{2} \mathrm{Rh}$ (1420.76): C, 53.26; H, 4.40; N, 3.94. Found: C, 53.33; H, 4.53; N, 3.76.

[RhI $\mathbf{I}_{\mathbf{3}}$ (dicarbene) $\mathbf{P P h}_{\mathbf{3}}$ ] (6). A mixture of $\mathbf{2 b}$ (40 mg, 0.02 mmol) and $\mathrm{PPh}_{3}(26 \mathrm{mg}, 0.1 \mathrm{mmol})$ in $\mathrm{CH}_{2} \mathrm{Cl}_{2}(5 \mathrm{~mL})$ was stirred at $\mathrm{rt}$ for $2 \mathrm{~h}$. After solvent evaporation, the residue was purified by gradient column chromatography $\left(\mathrm{SiO}_{2}\right.$; first $\mathrm{CH}_{2} \mathrm{Cl}_{2}$ then $\mathrm{CH}_{2} \mathrm{Cl}_{2}$ /acetone, 1:1), thus affording complex $\mathbf{6 a}(37 \mathrm{mg}$, 95\%). ${ }^{1} \mathrm{H}$ NMR $\left(\mathrm{CD}_{3} \mathrm{CN}, 400 \mathrm{MHz}, 333 \mathrm{~K}\right): \delta 7.7-7.15(\mathrm{~m}$, $\left.27 \mathrm{H}, \mathrm{H}_{\text {aryl }}, \mathrm{H}_{\mathrm{imi}}\right), 5.91\left(\mathrm{~d}, 1 \mathrm{H},{ }^{2} J_{\mathrm{HH}}=13.2 \mathrm{~Hz}\right.$, low-field AX part of $\left.\mathrm{NCH}_{2} \mathrm{~N}\right), 5.03\left(\mathrm{~d}, 1 \mathrm{H},{ }^{2} \mathrm{~J}_{\mathrm{HH}}=13.2 \mathrm{~Hz}\right.$, high-field $\mathrm{AX}$ part of $\left.\mathrm{NCH}_{2} \mathrm{~N}\right), 3.88-3.73\left(\mathrm{~m}, 4 \mathrm{H}, \mathrm{CH}_{2} \mathrm{CH}_{2} \mathrm{CH}_{2} \mathrm{CH}_{3}\right)$, 1.68-1.27 (m, 4H, $\left.\mathrm{CH}_{2} \mathrm{CH}_{2} \mathrm{CH}_{2} \mathrm{CH}_{3}\right), 1.14-0.96$ (m, 4H, $\left.\mathrm{CH}_{2} \mathrm{CH}_{2} \mathrm{CH}_{2} \mathrm{CH}_{3}\right), \quad 0.77 \quad\left(\mathrm{t}, \quad 6 \mathrm{H}, \quad{ }^{3} J_{\mathrm{HH}}=7.3 \mathrm{~Hz}\right.$, $\left.\mathrm{CH}_{2} \mathrm{CH}_{2} \mathrm{CH}_{2} \mathrm{CH}_{3}\right) .{ }^{13} \mathrm{C}\left\{{ }^{1} \mathrm{H}\right\}$ NMR $\left(\mathrm{CD}_{3} \mathrm{CN}, 100 \mathrm{MHz}, 333 \mathrm{~K}\right)$ : $\delta 143.9\left(\mathrm{C}_{\mathrm{imi}}\right), 135.8\left(\mathrm{C}_{\text {aryl-P }},{ }^{3} J_{\mathrm{CP}}=8.2 \mathrm{~Hz}\right), 133.5\left(\mathrm{C}_{\mathrm{imi}}\right), 132.1$ $\left(\mathrm{C}_{\text {aryl-imi }}\right), 131.6\left(\mathrm{C}_{\text {aryl-imi }}\right), 131.1\left(\mathrm{C}_{\text {aryl-P }},{ }^{2} J_{\mathrm{CP}}=17 \mathrm{~Hz}\right), 131.0$ $\left(\mathrm{C}_{\text {aryl-P }}\right), 129.2\left(\mathrm{C}_{\text {aryl-P, }},{ }^{1} J_{\mathrm{CP}}=10.0 \mathrm{~Hz}\right), 122.7\left(\mathrm{C}_{\text {aryl-imi }}\right), 61.9$ $\left(\mathrm{NCH}_{2} \mathrm{~N}\right), 49.2\left(\mathrm{CH}_{2} \mathrm{CH}_{2} \mathrm{CH}_{2} \mathrm{CH}_{3}\right), 33.0\left(\mathrm{CH}_{2} \mathrm{CH}_{2} \mathrm{CH}_{2} \mathrm{CH}_{3}\right)$, $20.3\left(\mathrm{CH}_{2} \mathrm{CH}_{2} \mathrm{CH}_{2} \mathrm{CH}_{3}\right), 13.7\left(\mathrm{CH}_{2} \mathrm{CH}_{2} \mathrm{CH}_{2} \mathrm{CH}_{3}\right), \mathrm{C}-\mathrm{Rh}$ not resolved. ${ }^{31} \mathrm{P}\left\{{ }^{1} \mathrm{H}\right\}$ NMR $\left(\mathrm{CD}_{2} \mathrm{Cl}_{2}, 162 \mathrm{MHz}\right): \delta 19.4\left(\mathrm{~d},{ }^{1} J_{\mathrm{PRh}}\right.$ $=112.8 \mathrm{~Hz}$ ). Anal. Calcd for $\mathrm{C}_{45} \mathrm{H}_{47} \mathrm{I}_{3} \mathrm{~N}_{4} \mathrm{PRh}(1158.47): \mathrm{C}$, 46.65; H, 4.09; N, 4.84. Found: C, 46.55; H, 3.98; N, 4.75.

[RhI $\mathbf{~}_{2}$ (dicarbene)(dppe)]I (7). Following a similar procedure as for $\mathbf{6}$, reaction of $\mathbf{2 b}$ (40 $\mathrm{mg}, 0.02 \mathrm{mmol})$ with dppe (21 mg, $0.05 \mathrm{mmol})$ yielded complex 7 as a yellow powder $(50 \mathrm{mg}$, $95 \%) .{ }^{1} \mathrm{H}$ NMR $\left(\mathrm{CD}_{2} \mathrm{Cl}_{2}, 500 \mathrm{MHz}, 273 \mathrm{~K}\right): \delta 7.70-7.38(\mathrm{~m}$, $\left.28 \mathrm{H}, \mathrm{H}_{\text {aryl }}\right), 7.23$ (m, $2 \mathrm{H}, \mathrm{H}_{\text {aryl }}$ ), 7.2 (br, $2 \mathrm{H}, \mathrm{NCH}_{2} \mathrm{~N}$ ), 6.74 (s, $\left.2 \mathrm{H}, \mathrm{H}_{\mathrm{imi}}\right), 3.80\left(\mathrm{~m}, 4 \mathrm{H}, \mathrm{CH}_{2} \mathrm{CH}_{2} \mathrm{CH}_{2} \mathrm{CH}_{3}\right), 3.21$ (m, 4H, $\mathrm{PCH}_{2}$ ), $1.58\left(\mathrm{~m}, 4 \mathrm{H}, \mathrm{CH}_{2} \mathrm{CH}_{2} \mathrm{CH}_{2} \mathrm{CH}_{3}\right), 1.18\left(\mathrm{~m}, 4 \mathrm{H}, \mathrm{CH}_{2} \mathrm{CH}_{2} \mathrm{CH}_{2} \mathrm{CH}_{3}\right.$ ), $0.81\left(\mathrm{~m}, 6 \mathrm{H}, \mathrm{CH}_{2} \mathrm{CH}_{2} \mathrm{CH}_{2} \mathrm{CH}_{3}\right) \cdot{ }^{13} \mathrm{C}\left\{{ }^{1} \mathrm{H}\right\} \mathrm{NMR}\left(\mathrm{CD}_{2} \mathrm{Cl}_{2}, 125\right.$ $\mathrm{MHz}, 273 \mathrm{~K}): \delta 142.5\left(\mathrm{C}_{\mathrm{imi}}\right), 136.8\left(\mathrm{C}-\mathrm{Rh},{ }^{1} J_{\mathrm{CRh}}=32.7 \mathrm{~Hz}\right.$, $\left.{ }^{2} J_{\mathrm{CP} \text { cis }}=10 \mathrm{~Hz},{ }^{2} J_{\mathrm{CP} \text { trans }}=147 \mathrm{~Hz}\right), 133.2\left(\mathrm{br}, \mathrm{C}_{\text {aryl-P) }}, 131.9\right.$ $\left(\mathrm{C}_{\text {aryl-imi }}\right), 129.8\left(\mathrm{C}_{\text {aryl-imi }}\right), 129.7\left(\mathrm{C}_{\text {aryl-P }},{ }^{1} J_{\mathrm{CP}}=17 \mathrm{~Hz}\right), 129.7$ $\left(\mathrm{C}_{\text {imi }}\right), 129.5\left(\mathrm{C}_{\text {aryl-P }}\right), 127.3\left(\mathrm{C}_{\text {aryl-imi }}\right), 127.2\left(\mathrm{C}_{\text {aryl-P }},{ }^{2} J_{\mathrm{CP}}=4.4\right.$ $\mathrm{Hz}), 120.8\left(\mathrm{C}_{\text {aryl-imi }}\right), 60.3\left(\mathrm{NCH}_{2} \mathrm{~N}\right), 47.3\left(\mathrm{CH}_{2} \mathrm{CH}_{2} \mathrm{CH}_{2} \mathrm{CH}_{3}\right)$, $31.6\left(\mathrm{CH}_{2} \mathrm{CH}_{2} \mathrm{CH}_{2} \mathrm{CH}_{3}\right), 26.9\left(\mathrm{~m}, \mathrm{PC}_{2} \mathrm{H}_{4} \mathrm{P}\right), 18.9\left(\mathrm{CH}_{2} \mathrm{CH}_{2} \mathrm{CH}_{2-}\right.$ $\left.\mathrm{CH}_{3}\right), 12.8\left(\mathrm{CH}_{2} \mathrm{CH}_{2} \mathrm{CH}_{2} \mathrm{CH}_{3}\right) .{ }^{31} \mathrm{P}\left\{{ }^{1} \mathrm{H}\right\} \mathrm{NMR}\left(\mathrm{CD}_{2} \mathrm{Cl}_{2}, 162\right.$ $\mathrm{MHz}, 273 \mathrm{~K}): \delta 38.9\left(\mathrm{~d},{ }^{1} J_{\mathrm{RhP}}=60.5\right)$. Anal. Calcd for $\mathrm{C}_{53} \mathrm{H}_{56} \mathrm{I}_{3} \mathrm{~N}_{4} \mathrm{P}_{2} \mathrm{Rh}$ (1294.60): C, 49.17; H, 4.36; N, 4.33. Found: C, 49.00; H, 4.20; N, 4.31 .

Typical Procedure for Catalytic Transfer Hydrogenation. The catalyst was either used as a solution $(0.6 \mathrm{~mL}, 4 \mathrm{mM}$ in $i \mathrm{PrOH}, 5 \mu \mathrm{mol} \mathrm{Rh}$ ) or weighed off directly into the reaction flask. It was stirred, together with $\mathrm{KOH}(0.05 \mathrm{~mL}$ of $2 \mathrm{M}$ solution in $\left.\mathrm{H}_{2} \mathrm{O}, 0.1 \mathrm{mmol}\right)$ and $i \mathrm{PrOH}(5.0 \mathrm{~mL})$ at reflux for $10 \mathrm{~min}$. Then the ketone $(1.0 \mathrm{mmol})$ was added at once. Aliquots $(0.2 \mathrm{~mL})$ were taken at fixed times, quenched in hexane $(2 \mathrm{~mL})$, and filtered through a short path of silica, and the silica was washed with diethyl ether or tert-butyl methyl ether. The combined organic filtrates were evaporated and analyzed by ${ }^{1} \mathrm{H}$ NMR spectroscopy.

Structure Determination and Refinement of the Complexes. A suitable single crystal was mounted on a Stoe Mark II-imaging plate diffractometer system (Stoe \& Cie, 2002) equipped with a graphite monochromator. Data collection was performed at $-100{ }^{\circ} \mathrm{C}\left(-80{ }^{\circ} \mathrm{C}\right.$ for $\left.\mathbf{3 f}\right)$ using Mo $\mathrm{K} \alpha$ radiation $(\lambda=0.71073 \AA)$ with a nominal crystal to detector distance of $70 \mathrm{~mm}$ (for 3f), $100 \mathrm{~mm}$ (for 3a, 3c, and 3d), and $135 \mathrm{~mm}$ (for $\mathbf{2 b}, \mathbf{3 b}$, and 7), respectively. All structures were solved by direct methods using the program SHELXS-97 and refined by full matrix least-squares on $F^{2}$ with SHELXL-97. ${ }^{29}$ The hydrogen atoms were included in calculated positions and treated as riding

(29) Sheldrick, G. M. Acta Crystallogr. A 2008, 64, 112. 


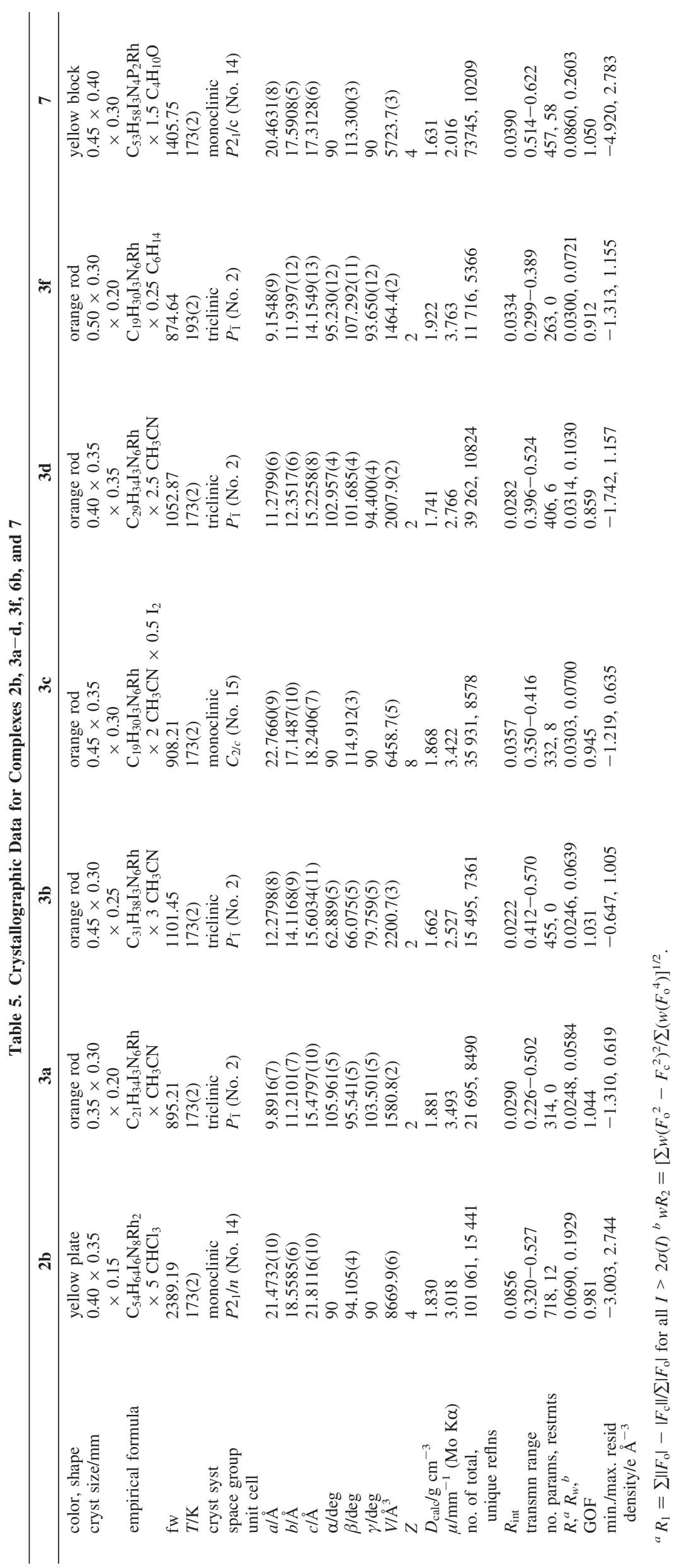


atoms using SHELXL-97 default parameters. All non-hydrogen atoms were refined anisotropically. A semiempirical absorption correction was applied using MULscanABS as implemented in PLATON03. ${ }^{30}$

The binuclear complex $\mathbf{2 b}$ crystallizes with five $\mathrm{CHCl}_{3}$ molecules per asymmetric unit (six positions, of which two are half-occupied and two are disordered). In compound $\mathbf{3 c}$, one of the two cocrystallized acetonitrile molecules and the $\mathrm{I}_{2}$ molecule are disordered. Complex 3d crystallizes with three acetonitrile molecules per asymmetric unit; one of them is half-occupied. The cocrystallized hexane molecule in $\mathbf{3 f}$ is on a special position and half-occupied. It is strongly disordered, and therefore, the SQUEEZE option in PLATON has been used to remove the electron density corresponding to the hexane molecule. Nevertheless it has been included in all further calculations. In the structure of 7, two strongly disordered ether molecules are cocrystallized. It was not possible to find a reasonable model defining the disorder. The SQUEEZE instruction in PLATON03 ${ }^{30}$ was used to calculate the potential solvent-accessible area in the unit cell; $926 \AA^{3}$ was calculated containing about 260 electrons. Therefore, 6 ether molecules $(6 \times 42$ electrons $)$ per unit cell were included in all further calculations. Further details on data collection and refinement parameters are collected in Table 5. Crystallographic data (excluding structure factors) for the structures $\mathbf{2 b}, \mathbf{3 a}-\mathbf{d}, \mathbf{3 f}$, and $\mathbf{7}$ have been deposited with the Cambridge Crystallographic Data Centre as supplementary publication nos. CCDC 688121-688127. Copies of the data can be obtained free of charge on application to CCDS, 12 Union Road, Cambridge CB2 1EZ, UK [fax: (int.) +44-1223-336-033; e-mail: deposit@ccds.cam.ac.uk].

Acknowledgment. We thank Mr. F. Fehr for technical assistance. This research was supported by the Swiss National Science Foundation and Sasol. M.A. is very grateful for an Alfred Werner Assistant Professorship.

(30) Spek, A. L. J. Appl. Crystallogr. 2003, 36, 7. 